\title{
Maintaining a Reputation for Consistently Beating Earnings Expectations and the Slippery Slope to Earnings Manipulation
}

\author{
Jenny Chu \\ Judge Business School \\ University of Cambridge \\ j.chu@jbs.cam.ac.uk \\ Patricia M. Dechow* \\ Marshall School of Business \\ University of Southern California \\ patricia.dechow@marshall.usc.edu \\ Kai Wai Hui \\ Faculty of Business and Economics \\ University of Hong Kong \\ kaiwai@hku.hk \\ Annika Yu Wang \\ Bauer College of Business \\ University of Houston \\ annikawang@bauer.uh.edu
}

November 16, 2018

\begin{abstract}
* Corresponding Author. We are grateful to Michael Welker, Editor-in-Chief, Sarah McVay, Editor, and two anonymous referees for their helpful comments and suggestions. We also thank Brad Badertscher, Ted Christensen, Ilia Dichev, Weili Ge, Michelle Hanlon, Bjorn Jorgensen, Alastair Lawrence, Christian Leuz, Reuven Lehavy, Hai Lu, Sarah McVay, Jeffrey Ng, Peter Pope, K. Ramesh, Ethan Rouen (discussant at 2018 FARS Midyear Meeting), Catherine Schrand, Hollis Skaife (discussant at 2015 HKUST Accounting Research Symposium), Richard Sloan, Eugene Soltes, Jake Thomas, Holly Yang, Amy Zang, and workshop participants at Emory University, London School of Economics, Norwegian School of Economics, Rice University, Singapore Management University, Yale Accounting Research Conference (2015), UCLA Accounting Conference (2018), UC Berkeley, University of Georgia, and University of Western Australia for helpful comments. We thank the UC Berkeley Center for Financial Reporting and Management for research funding and for sharing the Accounting and Auditing Enforcement Releases dataset. A previous version of this paper was titled "The Valuation Premium for a String of Positive Earnings Surprises: The Role of Earnings Manipulation.”
\end{abstract}




\title{
Maintaining a Reputation for Consistently Beating Earnings Expectations and the Slippery Slope to Earnings Manipulation
}

\begin{abstract}
This paper investigates whether maintaining a reputation for consistently beating analysts' earnings expectations can motivate executives to move from "within GAAP" earnings management to "outside of GAAP" earnings manipulation. We analyze firms subject to SEC enforcement actions and find that these firms consistently beat analysts' quarterly earnings forecasts in the three years prior to the manipulation period and continue to do so by smaller "beats" during the manipulation period. We find that manipulating firms beat expectations around 86 percent of the time in the twelve quarters prior to the manipulation period (versus 75 percent for control firms) and that manipulation often ends with a miss in expectations. We document that executives of manipulating firms face strong stock market and CEO pressure to perform. Prior to the manipulation period, these firms have high analyst optimism, growing institutional interest, and high market valuations, along with powerful CEOs. Further, we find that maintaining a reputation for beating expectations is more important than CEO overconfidence and is incremental to CEO equity incentives for explaining manipulation. Our results suggest that pressure to maintain a reputation for beating analysts' expectations can encourage aggressive accounting and, ultimately, earnings manipulation.
\end{abstract}

Keywords: earnings manipulation; consecutively beating earnings expectations; market pressure; CEO overconfidence; CEO power; reputation; goals; reference-dependent preferences; analysts' forecasts and recommendations; institutional investors; overvaluation.

JEL classification: G12, M41

Data availability: All data are available from sources identified in the text. 


\section{INTRODUCTION}

This study investigates whether maintaining a reputation for consistently beating analysts' earnings per share (EPS) forecasts is an important motivation for executives to engage in earnings manipulation (for simplicity, we use the term "beating" to refer to both meeting or beating analysts' EPS forecasts). We hypothesize that executives can become so focused on beating consensus EPS forecasts that, similar to athletes engaging in competition, they experience "tunnel vision." That is, they lose sight of the big picture and do "whatever it takes" to meet their goal. We hypothesize that when executives build a reputation for consistently beating expectations, they experience growing pressure to maintain their reputation. This intensifying pressure can create an escalating commitment problem that leads executives to initially engage in earnings management techniques that are within Generally Accepted Accounting Principles ("within GAAP"), but as expectations rise, executives use increasingly aggressive techniques. Ultimately, in some firms, executives become so desensitized to their accounting choices that they move "outside of GAAP" to beat earnings expectations.

We test our predictions using a sample of firms that are subject to Securities and Exchange Commission (SEC) enforcement actions summarized in Accounting and Auditing Enforcement Releases (AAERs). For this sample of firms, there is unambiguous evidence that executives have used accounting discretion "outside of GAAP" to manipulate earnings. We document that relative to the population and to a sample matched on the propensity to consistently beat analysts' expectations, AAER firms are more likely to have consistently beaten analysts' expectations in the three years prior to the manipulation period. We find that manipulating firms are beating expectations approximately 86 percent of the time in the three years leading up to the manipulation period (versus 75 percent for non-AAER firms). However, beating expectations becomes increasingly difficult for manipulating firms. Specifically, the 
average magnitude of the earnings surprise (the difference between reported EPS and analysts' forecasts of EPS) declines as the manipulation period approaches and is smallest during the manipulation period. In addition, after manipulation ends, the manipulating firms typically miss expectations. This evidence suggests that beating expectations is an important goal for executives who ultimately manipulate earnings.

We hypothesize that pressure on executives to consistently beat expectations can come from two broad sources: (1) external pressure from stock market participants and (2) internal pressure from the company's leadership. Firms that consistently beat analysts' expectations are likely to initially have strong economic performance. If analysts presume that the strong economic performance will continue, then they are likely to forecast high future earnings growth and issue "strong buy" recommendations. In addition, institutional investors are likely to notice the strong performance and purchase the shares. As a consequence, firms that consistently beat expectations trade at a valuation premium (e.g., Bartov et al., 2002; Kasznik and McNichols, 2002). We hypothesize that once the premium is earned, executives face pressure to continue to beat expectations to maintain the high valuation and to avoid disappointing investors. Thus, the valuation premium itself can become a source of pressure to manipulate earnings (Jensen, 2005). When managers find that they do not have enough "within GAAP" accounting flexibility to beat expectations, they could turn to "outside of GAAP" accounting techniques to enable them to continue to beat expectations.

The company's internal leadership could also create an environment in which there is strong pressure on executives to meet expectations. A chief executive officer (CEO) with strong equity incentives could exert more pressure on other executives to beat expectations, since his or her compensation will be particularly sensitive to stock price declines should those expectations not be met (e.g., Cheng and Warfield, 2005). Feng et al. (2011) provide evidence that CEOs of manipulating firms 
have higher equity incentives and appear to pressure the chief financial officer (CFO) to engage in earnings manipulation. We extend this line of research by investigating whether the manipulation is aimed at consistently beating analysts' expectations. In addition to equity incentives, overconfidence could also play a role. Schrand and Zechman (2012) provide evidence that overconfident CEOs, as measured by Malmendier and Tate (2005), are more likely to engage in manipulation. ${ }^{1}$ Within our context, an overconfident CEO may consider aggressive accounting as a justifiable tool to beat expectations because of a belief that the firm will perform better in the future. Finally, the CEO must have sufficient power to influence other executives (e.g., Dechow et al., 1996; Feng et al., 2011). We measure power in two ways: whether the $\mathrm{CEO}$ has power over the board (CEO/chair duality and the proportion of independent directors), and whether compared to control firms the CEO has a larger pay slice (is paid a larger percentage of the compensation pool available to top five executives). Thus, CEOs with stronger equity incentives, who are overconfident and powerful, could put more pressure on executives to engage in manipulation to continue a trend of beating earnings expectations.

Furthermore, we conjecture that corporate executives are highly competitive and goal-oriented people. Therefore, once the management team views beating expectations as a goal, they will exert effort to achieve this goal and will feel a sense of loss should they miss it. In other words, beating expectations could become an innate or intrinsic reference point to executives. For example, consider the following quote from an interview conducted by Soltes (2016, p. 199):

"(T)he Wall Street number was pure. It was somebody else independent of me saying, "Stephen, this is what you need to aim for this quarter." I would judge my success on the ability to make that number. If we achieved that number, it was an endorsement that we were doing the right things. If we missed that number, then it was a reflection that we hadn't performed as well as we should have. My goal was just to get to or over that number - and if I did that, I succeeded." (Stephen Richards, Global Head of Sales at Computer Associates)

\footnotetext{
${ }^{1} \mathrm{CEO}$ overconfidence is measured as an indicator variable that equals one if the natural $\log$ of the sum of in-the-money unexercised exercisable options held by the CEO is greater than the three-digit SIC industry median, and zero otherwise. Overconfident CEOs are predicted to hold in-the-money options for longer than optimal because they anticipate unrealistic increases in their firms' stock prices (Malmendier and Tate, 2005).
} 
If executives have strong reference-dependent preferences and use analysts' expectations as a point of reference, then this could create a dynamic in which a move from "within GAAP" to "outside of GAAP" accounting becomes part of an escalating commitment to continuously beat expectations. ${ }^{2}$

We compare manipulating firms to the population and to firms that are propensity-matched on the likelihood of consistently beating analysts' expectations. Consistent with manipulating firms facing strong market pressure, we find that in the three years leading up to the manipulation period, these firms have high price-to-earnings (PE) multiples, experience growing institutional ownership, have analysts making optimistic long-term growth forecasts, and have a high proportion of analysts recommending the stock as "buy" and "strong buy." In addition, consistent with prior research documenting strong CEO pressure, we find that manipulating firms have more powerful CEOs with stronger equity incentives. However, we find that CEO overconfidence is only significant when we compare manipulating firms to the population. After propensity-score matching we find no evidence that CEO overconfidence explains manipulation, suggesting that our overconfidence proxy contains noise or that overconfidence is not an important determinant of manipulation after controlling for firm characteristics.

Finally, we perform multivariate regression analysis and examine whether a prior reputation for beating analysts' forecasts (the percentage of quarters that firms beat analysts' forecasts in the prior three years) is incrementally significant to market pressure and CEO pressure in explaining manipulation. We document strong evidence that our reputation proxy is a significant determinant of manipulation after considering pressure from the stock market and CEOs. Overall, our results are consistent with the notion that executive teams care about maintaining a reputation for beating expectations beyond pressure induced by the stock market and CEOs. This could be because (1) these

\footnotetext{
${ }^{2}$ Research in behavioral economics suggests that people measure their happiness based on reference points (Tversky and Kahneman, 1991) and will exert effort to meet reference points even when there are no monetary benefits (e.g., Allen et al., 2016). We do not attempt to determine whether the greater sense of loss stems from the executive's utility function (as suggested by the quote from Stephen Richards), the corporate culture, or contractual incentives.
} 
executives have high reference-dependent preferences, (2) these executives believe that maintaining a reputation is important for future compensation or promotion reasons, or (3) the reputation proxy captures unexplained aspects of market or leadership related pressures. Whatever the ultimate reason, our results suggest that a reputation for consistently beating expectations is an important determinant of “outside of GAAP” manipulation.

Our paper builds on and contributes to four areas of research. First, we contribute to research investigating whether firms manage earnings to consistently beat analysts' forecasts. Prior research has weak or ambiguous results when investigating this question primarily because discretionary accrual proxies used to identify manipulating firms are correlated with growth and other firm characteristics. For example, Matsumoto (2002) finds evidence of significant discretionary accruals in univariate tests but not in multivariate tests. Bartov et al. (2002) isolate firms that meet expectations using discretionary accruals and find that they enjoy only slightly smaller premiums than other consistent beaters and exhibit superior future earnings performance relative to other firms. They suggest that managers could be signaling future performance by using earnings and expectations management. However, an alternative explanation is that discretionary accruals are measured with error and the error is correlated with growth. Our research aims to provide insights into the role of manipulation in expectations management and differs in two ways from prior research. First, we avoid interpretation problems with discretionary accruals by using a sample of firm-years identified by the SEC as having unambiguously manipulated earnings. Second, rather than analyze whether consistent beaters engage in earnings management, we analyze whether identified manipulators consistently beat expectations. ${ }^{3}$ This research

\footnotetext{
${ }^{3}$ Myers et al. (2007) examine firms that report quarterly EPS increases for five consecutive years and argue that these firms are managing earnings. However, since their sample consists of the population of firms that have achieved this feat, they do not have an obvious control sample for their tests. Our analysis avoids this interpretation difficulty because we can compare the beating behavior of identified manipulators directly to the population of non-AAER firms as well as to a propensityscore-matched non-AAER sample.
} 
design enables us to investigate whether manipulating firms are consistent beaters, both before and during the manipulation period. Our results suggest that firms with long strings of positive earnings surprises are likely to have "true" earnings growth in early years, consistent with the findings in Bartov et al. (2002) and Kasznick and McNichols (2002). It is only later in the string, when growth slows, that manipulation is likely to take place. ${ }^{4}$ Thus, researchers are most likely to detect earnings management towards the end of the string, just before the positive earnings string breaks.

Second, we extend research that finds firms that consistently beat benchmarks, such as prior year's earnings and analysts' forecasts, have higher PE multiples than firms that have similar growth in terms of underlying fundamentals but do not consistently beat benchmarks (e.g., Barth et al., 1999; Bartov et al., 2002; Kasznik and McNichols, 2002). This line of research has difficulty explaining the empirically documented premium. Barth et al. (1999) suggest that investors pay a premium for less volatile earnings. However, this preference is difficult to explain when investors hold diversified portfolios. Kasznik and McNichols (2002) similarly suggest that investors could view these firms as less risky and reward them with a lower cost of capital. Bartov et al. (2002) find no evidence of investor overreaction and suggest that the premium is due to anticipated improved future performance. We conjecture that the valuation premium is attributable to improved recognition and liquidity of these stocks (e.g., Merton, 1987; Lehavy and Sloan, 2008). Consistent with this explanation, we document that prior to the manipulation period as AAER firms are building their reputations for consistently beating expectations, analysts are recommending these stocks and have optimistic growth expectations, while institutional investors are increasing their holdings in these firms.

\footnotetext{
${ }^{4}$ Kasznick and McNichols (2002) do not investigate earnings management but note "the extent to which firms meet expectations by manipulating earnings or expectations and the consequences of such manipulation for valuation remain open questions for future research" (p. 757).
} 
Third, we build on Jensen's (2005) theory concerning the agency costs of overvalued equity. Jensen (2005) suggests that one of the costs of overvalued equity is that managers feel compelled to maintain the high equity valuation. Our evidence suggests that the initial overvaluation (as reflected in a high PE multiple) is a consequence of firms consistently beating earnings expectations, and that managers manipulate earnings to continue to beat expectations in an effort to maintain their reputations and stock prices. Relatedly, we extend Badertscher's (2011) evidence that once firms are overvalued, they engage in real and accrual management over the next five years. Our results suggest that a plausible underlying managerial motivation for the earnings management documented by Badertscher (2011) is to maintain a reputation for consistently beating analysts' forecasts.

Finally, we build on research examining organizational and CEO attributes that influence earnings manipulation. Schrand and Zechman (2012) suggest that CEOs move down the "slippery slope" from accrual management to "outside of GAAP" earnings manipulation because of their overconfidence about future performance. Other researchers suggest that CEOs' power to influence organizational goals and their financial incentives encourage manipulation (e.g., Beasley, 1996; Dechow et al., 1996; Efendi et al., 2007; Feng et al., 2011). We add to this research by suggesting an underlying motivation for the manipulation is the desire to consistently beat analysts' expectations. CEOs with large equity-based incentives, who are overconfident, who have power to influence other executives could also be particularly competitive and goal-oriented. If such a CEO sets beating analysts' expectations as a goal for the firm and the firm builds a reputation for beating expectations, then other executives will also view maintaining the reputation as important to themselves and to the firm. This in turn could lead to the acceptance of increasingly aggressive accounting techniques. Our empirical evidence also corroborates motives identified in Soltes (2016). Soltes (2016) interviews executives that have engaged in misconduct and notes that these executives appear to lose perspective and lack awareness of their wrongful actions, 
often justifying their actions as in the interest of current shareholders and employees. Our evidence suggests that executives can lose perspective when they set consistently beating analysts' expectations as a goal. Overall, our results suggest that consistently beating expectations does not always indicate strong economic growth. Instead, it can indicate an executive team that is overly focused on expectations management and maintaining the firm's stock valuation premium. These results are informative to investors, analysts, auditors, and regulators.

\section{PREDICTIONS}

Exhibit 1 provides the framework for our predictions. Prior research suggests that firms that consistently beat analysts' earnings expectations earn a valuation premium, indicated by a higher PE multiple (e.g., Bartov et al., 2002; Kasznick and McNichols, 2002). In addition, firms with similar economic performance that do not consistently beat expectations do not earn the premium. Thus, both strong economic performance and a reputation for consistently beating expectations are required to obtain the valuation premium. In Panel A, we highlight how the premium is likely to be earned. The combination of strong economic performance and the consistent beating of expectations could encourage analysts to follow and promote the stock to clients. In addition, as clients buy the stock, investor recognition increases, thus creating more demand for the stock and encouraging institutional investment. The strong economic performance also helps build the executive team's reputation for being of high quality and ability. This combination is likely to increase the market value of the executives in labor markets. ${ }^{5}$

\footnotetext{
${ }^{5}$ Graham et al. (2005) survey executives and find that executives believe that meeting expectations is an indicator of managerial ability. Likewise, missing expectations is viewed as costly to career mobility.
} 
Panel B of Exhibit 1 focuses on how a reputation for consistently beating expectations can put pressure on executives to continue beating expectations even when true growth is slowing. The strong prior economic performance can encourage analysts to ratchet up growth expectations for the firm and recommend the stock as a "buy" even when the firm is trading at a high value. Thus, missing expectations could hurt the executive team's reputation with analysts and thereafter induce potential downgrades in stock recommendations. In addition, as institutional investors increase their holdings in the firm, executives could feel pressure to maintain the stock valuation to avoid disappointing these important investors since greater institutional ownership is associated with lower stock price volatility, higher liquidity, and greater ease in issuing new equity and debt (e.g., Bushee and Noe, 2000; Bushee and Miller, 2012).

When the firm's growth begins to slow, and executives become apprehensive about missing earnings expectations, they could use a number of financial reporting tools to beat expectations. The first tool is to lower guidance (e.g., Matsumoto, 2002). However, firms may be unable to consistently beat market expectations using management guidance alone. First, managers may be unable to repeatedly lower guidance to lower analysts' expectations. Expectations management tends to lead to forecast errors when the actual earnings are announced. Thus, a reputation for biased guidance reduces the effectiveness of future management guidance because investors will discount the guidance and adjust their expectations to take into account the bias (e.g., Williams, 1996; Rogers and Stocken, 2005). Second, lowering guidance also sends a negative signal about future performance to investors. Third, analysts' expectations can become more difficult to beat over time. Prior research finds that analysts' forecasts become more accurate over time as analysts gain firm-specific experiences, suggesting that analysts react to forecast errors by adjusting the level of their future forecasts (e.g., Mikhail et al., 1999). 
Thus, beating analysts' forecasts through guidance could become increasingly more difficult as an earnings string lengthens.

A second tool that managers could use to beat expectations is "within GAAP" earnings management, either through accrual management or the structuring of transactions. The use of "within GAAP" earnings management also has limitations because accruals tend to reverse in subsequent periods. If managers manipulate earnings upward in a year using positive accruals, the negative reversals in future years will lead to even larger future earnings gaps (e.g., DeFond and Park, 2001; Allen et al., 2013). This property of accruals makes continued upward earnings manipulation more costly and difficult in the subsequent periods. A third tool managers could use is to disclose non-GAAP earnings (Black et al., 2017). However, a growing difference between GAAP and non-GAAP earnings could also raise red flags with investors (e.g., Doyle et al., 2013). Thus, when the firm reaches a point where these "within GAAP" tools are no longer sufficient to beat ever-growing expectations, managers could turn to "outside of GAAP" earnings manipulation to boost earnings. ${ }^{6}$ Similar to professional athletes who justify the use of performance-enhancing drugs to avoid disappointing fans and sponsors, executives could justify the use of "outside of GAAP" earnings manipulation to avoid disappointing analysts, investors, and the firm's leadership.

We have three predictions based on this discussion:

P1: Executives engage in "outside of GAAP" earnings manipulation to consistently beat analysts" quarterly earnings expectations.

P2: Executives engage in "outside of GAAP" earnings manipulation because they have built reputations for consistently beating analysts' quarterly earnings expectations prior to the manipulation period.

P3: Executives engage in "outside of GAAP" earnings manipulation because they face strong market pressure to continue to beat earnings expectations.

\footnotetext{
${ }^{6}$ Earnings management tools occur along a continuum, initially being within GAAP but becoming increasingly aggressive until eventually the firm moves to intentional manipulation and outside of GAAP misstatements (see, for example, Figure 1 in Christensen et al., 2017, or Figure 1 in Dechow and Skinner, 2000).
} 
Panel B of Exhibit 1 highlights that the executive team could also face pressure generated from within the firm, specifically from the $\mathrm{CEO}$, to continue to beat expectations. If true earnings performance falls short of expectations, overconfident CEOs may view aggressive accounting as appropriate because of their strong belief that the firms' future performance will improve (Schrand and Zechman, 2012). ${ }^{7}$ Thus, overconfident CEOs could pressure their executive teams to beat expectations by making accounting choices that fall "outside of GAAP." ${ }^{8}$ We measure overconfidence using the proxy identified by Malmendier and Tate (2005) and employed by Schrand and Zechman (2012). Powerful CEOs facing insufficient monitoring from the board are better able to influence other employees within the organization to adjust accounting procedures and thereafter engage in earnings manipulation (e.g., Dechow et al., 1996; Bebchuk et al., 2011). CEOs could also face personal financial incentives from their compensation contracts to beat expectations. Stock-based compensation, in particular, aligns the CEO's personal financial interests closely to the firm's stock performance and therefore could induce financial statement manipulation to maintain or inflate the stock price (e.g., Dechow et al., 1996; Cheng and Warfield, 2005; Jiang et al., 2010; Feng et al., 2011).

Note that a pattern of consistently beating expectations is likely to reflect both strong economic performance and a strategic decision on the part of the executive team to make beating expectations an organizational goal. If employees accept and act on this goal, competitive, goal-oriented executives could begin to judge their own self-worth and value to the organization in terms of their ability to beat

\footnotetext{
${ }^{7}$ Overconfidence is described by Moore and Healy (2008) in three distinct ways: (1) overestimation of one's actual performance, (2) believing one will perform better than others, and (3) excessive precision in one's beliefs. Applying this description to our setting, an overconfident CEO could believe that their firm should: (1) always be able to beat analysts' expectations, (2) be able to beat expectations more than other firms, and (3) be able to produce earnings to meet an exact earnings forecast.

${ }^{8}$ For example, an overconfident CEO could believe the firm's products will have no returns and all customers will pay (no bad debt allowances) even though a neutral party (the SEC or auditor) would not believe this based on past and current information.
} 
expectations. ${ }^{9}$ Liu (2016) also suggests that senior managers' corruptive cultural biases affect their individual behavior which in turn increases the likelihood of accounting fraud. Thus, after controlling for market pressure as well as CEO overconfidence, power, and compensation incentives, a reputation for consistently beating expectations could also be a determinant of earnings manipulation.

\section{SAMPLE SELECTION}

Panel A of Table 1 summarizes the process for selecting the AAER sample. We use firms identified by the SEC as having manipulated annual earnings (i.e., firms subject to Accounting and Auditing Enforcement Releases, or AAER firms). We define the "manipulation period" as fiscal years in which the SEC identifies misstated annual earnings. Thus, if a firm manipulates one quarter's earnings but annual earnings are correctly stated, then it is not included in our sample. We begin with a total of 3,323 observations of AAERs issued between May 1982 and September 2013. We exclude repeating AAERs related to the same firm and incident, AAERs unrelated to financial statement fraud that would not affect reported earnings, and AAERs for which we cannot find Compustat or IBES identifiers. We require quarterly earnings data and annual financial data for each manipulation year identified by the SEC. This procedure results in a final sample of 392 AAER firm-year observations for 136 unique AAER firms from 1985 to 2010.

Table 1, Panel B summarizes the sample selection process for the non-AAER population. We use the population of all non-AAER firms (the "population") for comparison of results with the AAER firms. Our population consists of U.S. firms on IBES from 1985 to 2010, excluding all AAER firms

\footnotetext{
${ }^{9}$ The interviews performed by Soltes (2016) suggest that some of the manipulating executives evaluated themselves based on the achievement of goals. For example, on page 189, Jones of Symbol states “... We never grew up with someone saying you can't do it and therefore you are not going to hit a number. We always tried to come up with a solution whether it was for hitting a number or whether it was a solution for making a computer work right. We always came up with solutions... Whatever it took, you did it and got success from it."
} 
identified by the SEC from May 1982 to September 2013. We begin with 52,724 firm-year observations with IBES coverage. After the exclusion of AAER firms and the requirement of financial data, our final non-AAER sample consists of 43,939 non-AAER firm-year observations.

We also compare AAER firms to a sample of propensity-score-matched non-AAER firms. We match each AAER firm-year observation to one observation from the population based on their propensity to beat analysts' forecasts in all four quarters of a given fiscal year (we term this an all-one string, described in more detail below). The matching process enables us to control for possible correlated omitted variables (i.e., strong economic performance rather than earnings manipulation) that may explain firms' positive earnings strings. Therefore, in the first stage of propensity-score estimation, we model a firm's likelihood of achieving an all-one string using variables that capture economic fundamentals. We find that firms of larger size (SIZE), higher growth in profitability $(\triangle R O A)$, lower book-to-market $(B T M)$, and lower leverage $(L E V)$, are more likely to achieve all-one strings. In the second stage, to control for the economic fundamentals, we match AAER firms with population firms that have the closest propensity-score for achieving a string of positive earnings estimated using the four variables identified in the first stage. Table 1, Panel $\mathrm{C}$ evaluates the effectiveness of the matching procedure. The AAER sample is not significantly different from the one-to-one propensity-scorematched non-AAER sample with respect to innate firm characteristics. ${ }^{10}$

Exhibit 2 illustrates the construction of earnings strings for AAER firms in Panel A and for nonAAER firms in Panel B. We construct earnings strings based on quarterly earnings surprises. We

${ }^{10}$ In the model to estimate firms' propensity to consistently beat analysts' forecasts, we consider important firm characteristics, including firm size, book-to-market ratio, leverage, and change in profitability. The model has an area under ROC curve of 62.02 percent. Note that we do not match AAER firms and non-AAER firms exactly on years. Instead, we require that the sample period of the propensity-score-matched non-AAER sample covers the same period from 1985 to 2010 as the AAER sample. The estimation method allows us to have a closer score-matching of firm characteristics. In untabulated analysis we also match by year, industry (Fama and French's 12-industry classification), and closest firm size, and our inferences do not change. 
measure earnings surprise as the difference between the actual EPS and the most recent median analyst consensus EPS forecast prior to earnings announcements from the IBES unadjusted summary file. A firm-quarter observation receives a " 1 " for beating the consensus forecast and a " 0 " for missing. A fourquarter string observation consists of a series of ones and zeros based on whether the firm beats consensus forecasts from fiscal Q1 to Q4 during the fiscal year. Panel A illustrates string formation using Coca-Cola Company, Ltd as an example. Coca-Cola manipulated earnings from fiscal year 1997 to 1999 (see Appendix A for a discussion of AAER No. 2232). Throughout this three-year period, CocaCola managed to consistently beat the analyst consensus forecast for each quarter. Each four-quarter string begins in Q1 and ends in Q4 to facilitate the comparison with the population. Over its manipulation period, Coca-Cola contributes three string observations to the AAER sample and all three of them are all-one strings. Panel $\mathrm{B}$ and $\mathrm{C}$ of Exhibit 2 illustrates the string pattern and the construction of strings for non-AAER firms using Coca-Cola's matched counterpart Heinz. Each fiscal year with analyst data for all four quarters is classified as one string observation. Each string begins in Q1 and ends in Q4. Note that we avoid overlapping quarters in string construction but use fiscal year instead, so that it is easier to determine the size of the population and the proportion of firm-year observations with all-one strings. Avoiding overlapping quarters also facilitates the measurement and the inclusion of CEO-characteristic variables, as well as some F-score-generating variables that are only reported on an annual basis. In untabulated robustness analysis we allow overlapping strings (so the strings do not have to start in Q1) and results are qualitatively similar.

In our empirical analyses, we utilize two key variables that measure consistent beating behavior. The first is all-one string that as described previously, equals one when a firm beats the median analyst consensus EPS forecast in all four quarters of a year, and zero otherwise. We use the term AAER all-one string to describe AAER firm-year observations that beat analysts' forecasts in all four quarters of a 
manipulation year. The second is BEATPCT that measures the proportion of quarters that a firm beats the median analyst consensus EPS forecast for a specific period of time. For example, BEATPCT equals 75 percent if the firm is able to beat expectations in any three quarters of a fiscal year.

One concern with using firms identified by the SEC for manipulating earnings is that the SEC could use a string of consecutive earnings beats as a screen for identifying potential fraud firms. We therefore perform a news search of all AAER firms in our sample to determine the event that triggered the SEC investigation. Table 2 reports the number and the proportion of AAER firms for ten different triggers for the SEC investigation identified in news articles. We find that the SEC appears to be more reactive than proactive. Specifically, 58 percent of AAERs (54 percent for all-one string AAER firms) are triggered by financial restatements and for another 13 percent of the AAER sample, the SEC investigations are triggered by shareholder lawsuits. None of the SEC investigations are triggered by the firm reporting consecutive positive earnings surprises before or during the manipulation period. In addition, the SEC's Division of Economic Risk Analysis (DERA) was established in 2009. Our conversations with SEC staffers suggest that there was little use of systematic screening techniques to identify potential fraud firms during our sample period. Therefore, the SEC screening firms with a string of positive earnings surprises does not appear to be a major concern for selection bias in our study.

\section{EMPIRICAL RESULTS}

\subsection{Analysis of beating quarterly expectations during manipulation years}

Table 3 tests our prediction $P 1$. The table reports results on a firm-year basis, and details how many quarters AAER firms are able to beat expectations during any given manipulation year. For a fourquarter string, there are sixteen possible permutations and Table 3 compares the distribution of these sixteen string permutations across the AAER sample, the population, and the propensity-score-matched 
non-AAER sample. ${ }^{11}$ We categorize strings on the basis of whether the firm beats expectations in only one quarter, two quarters, three quarters, or all four quarters of a fiscal year. The results indicate that the all-one string $(1,1,1,1)$ is the most dominant pattern out of the sixteen possible permutations. Indeed, 54.85 percent of AAER firms achieve all-one strings during manipulation years, compared to 42.99 percent for the population and 46.94 percent for the matched sample. Table 3 also indicates that both the distribution of all-one strings and the overall distribution of the AAER sample are significantly different from that of the population and the matched sample. Note that if we relax the definition of an earnings string to "the firm must beat expectations in at least three quarters", then approximately 77.81 percent $(22.96 \%+54.85 \%)$ of AAER firm-years meet this requirement versus 65.46 percent for the population and 67.86 percent for the matched sample. Untabulated results indicate that these differences are also statistically significant. In summary, Table 3 indicates that AAER firms are more likely than non-AAER firms to consistently beat expectations during their manipulation years, which supports prediction $P 1$ that AAER firms appear to manipulate earnings to beat expectations.

We next provide evidence for prediction $P 2$ and analyze whether AAER firms have built reputations for beating expectations prior to the manipulation period. Panel A of Figure 1 provides a graphical representation of beating frequency for the AAER sample and the population. The observations are organized by event time, where the event is the first quarter of the first manipulation year $(M l)$. We then report the proportion of AAER firms that beat expectations in each of the twelve quarters before the first manipulation year (year Pre3 to Prel) and in each of the twelve quarters after the last manipulation year (year Post1 to Post3). Note that if a firm manipulates for more than one year, the remaining manipulation years are not reflected in the graph. However, the plot is similar when we

\footnotetext{
${ }^{11} \mathrm{We}$ focus on four-quarter strings since the number of possible permutations increases exponentially for strings longer than four quarters. For example, there are 256 different permutations for a string of eight quarters, compared to 16 permutations for a string of four quarters.
} 
take average values across all manipulation years. Panel A of Figure 1 indicates that the majority of AAER firms, around 80 to 90 percent, beat analysts' forecasts in the three years leading up to the first manipulation year. The proportion of beats remains high in the first manipulation year $(M 1)$ but we see a large decline in beats in the year immediately after manipulation stops (Post1). This is consistent with the end of manipulation coinciding with a greater likelihood of missing expectations. The plot is consistent with prediction $P 2$ and indicates that AAER firms have stronger reputations for beating analysts' expectations than the population before resorting to "outside of GAAP" manipulation.

Panel B of Figure 1 compares AAER firms that achieve an all-one string during the manipulation period (termed as all-one string AAER firms) to the population of firms that have also achieved an allone string during the fiscal year matched to the AAER firms' year M1. If an AAER firm has more than one all-one string, then we use the first year that the AAER firm achieves an all-one string as year $M 1$ in the figure. We provide this comparison since we expect AAER firms that have beaten expectations in all four quarters of a manipulation year to be particularly likely to be manipulating for the purpose of beating expectations. The plot in Panel B indicates that these AAER firms have consistently beaten expectations in the prior three years. However, in the three years following the manipulation period, these AAER firms are far less likely to beat expectations than matched non-AAER firms that have an all-one string. Thus, the end of the manipulation period coincides with a significant and long break in beating expectations, and this break is not experienced by non-AAER firms achieving all-one strings. In summary, both Panel A and B of Figure 1 suggest that AAER firms have strong reputations for consistently beating expectations, and that the end of the manipulation period coincides with AAER firms losing such reputations.

Table 4 provides a similar analysis to Figure 1, but instead of focusing on the percent of firms that beat expectations in each quarter, we analyze the data on a firm-basis and test the proportion of 
beats for a given firm over the three years prior to manipulation as well as during and after the manipulation period. Panel A indicates that the average AAER firm beats expectations 86.37 percent of the time in the three years leading up to the manipulation period, compared to 75.15 percent for the population and 78.02 percent for the matched non-AAER sample. These differences are statistically significant (t-statistic of 5.24 and 3.24 respectively), consistent with AAER firms having strong reputations for beating expectations. ${ }^{12}$ Panel A also reports the median magnitude of the earnings surprise for AAER firms and control samples. We calculate the quarterly earnings surprise in two ways. SURPRISE_EPS is calculated as the difference between the firm's reported EPS and the median analyst consensus EPS forecast. SURPRISE_\% is the difference between the firm's reported EPS and the median analyst consensus EPS forecast scaled by the absolute value of reported EPS. We take the average quarterly earnings surprise for each firm over the three-year period and Panel A reports the median earnings surprise across AAER firms (and across control firms). We report median values since average values tend to be impacted by a small number of large misses (negative outliers). Panel A indicates that AAER firms have larger earnings surprises than the two control samples in the three years prior to the manipulation period. SURPRISE_EPS is 0.11 for AAER firms compared to 0.02 for the population and 0.02 for the matched sample, with these differences being significant at the one percent level. Similar results are documented for SURPRISE_\%.

Panel B of Table 4 reports the percentage of beats and the magnitude of the earnings surprise in each of the three years prior to manipulation. SURPRISE_EPS is largest in the first year of the three-year period prior to the manipulation period $(0.21$ in Pre3) and declines to 0.07 in the year immediately prior

\footnotetext{
${ }^{12}$ Note that we do not have three years of quarterly forecasts before the manipulation period for all of the 136 AAER firms. There are 24 firms for which analysts provide only annual EPS forecasts, and we find that for these firms there are only two cases where the firm missed expectations. In addition, there are 38 firms for which manipulation coincided closely with the initiation of analyst coverage. Consistent with beating expectations being a motivation for the manipulation, we find that this subset of firms beat expectations over 85 percent of the time.
} 
to the manipulation period (Pre1). This decline is significant and suggests that AAER firms are finding it increasingly difficult to beat expectations as the manipulation period approaches. Panel C provides the proportion of beats and the magnitude of the earnings surprise in the first manipulation year as well as over the entire manipulation period. SURPRISE_EPS declines to 0.02 in the first manipulation year and is 0.01 for the entire manipulation period. Thus, during the manipulation period AAER firms are beating expectations by a smaller magnitude than prior to the manipulation period and appear best able to beat expectations in the first manipulation year. In addition, the small size of the "beat" suggests that AAER firms manipulate earnings just enough to achieve the goal of meeting expectations. A similar pattern is documented for SURPRISE_\%. These findings suggest that AAER firms resort to manipulation to continue the trend of meeting expectations. Finally, Panel D reports the percentage of beats in the year immediately after manipulation stops. The average AAER firm is only able to beat expectations in half of the quarters $(B E A T P C T=57.17 \%)$ and the median size of the beat is 0.00 for SURPRISE_EPS and a miss of -0.02 for SURPRISE_\%. Thus, the end of the manipulation period coincides with the firm losing its reputation for consistently beating expectations.

We next provide corroborating evidence that AAER firms first use their "within GAAP" accounting flexibility to boost earnings before turning to "outside of GAAP" techniques. Figure 2 provides the average working capital accruals (Panel A) and average total accruals (Panel B) for nonfinancial AAER firms relative to the manipulation period. Figure 2 indicates that AAER firms have both higher working capital accruals and total accruals than population firms in the three years prior to the first manipulation year and that these measures peak during the manipulation period. Figure 2 also shows a sharp decline in accruals after the manipulation period ends. We also provide plots for the subset of AAER firms that report all-one strings (that we conjecture are more likely to be manipulating earnings to beat analysts' forecasts). We find that these firms have higher levels of working capital 
accruals and total accruals than control firms and there are larger reversals after the manipulation ends. ${ }^{13}$ These accrual patterns are consistent with AAER firms being growth firms prior to the manipulation period. They also suggest that AAER firms could have used aggressive assumptions when calculating accruals before the manipulation period and resorted to "outside of GAAP" manipulation when they no longer had the accrual flexibility to meet expectations.

In summary, the results in Figure 1, Figure 2, and Table 4 indicate that prior to the manipulation period AAER firms are consistently beating expectations and continue to do so by smaller "beats" during the manipulation period. We document that as the manipulation period approaches the magnitude of the earnings surprise declines and the magnitude of accruals increases. This suggests that firms face more difficulty beating expectations and resort to earnings manipulation to achieve this goal. These results support predictions $P 1$ and $P 2$.

\subsection{Market pressure from analysts and investors}

Figure 3 provides the time-series patterns of variables that we hypothesize reflect market pressure from analysts. We predict that executives face more pressure to beat expectations when analysts are optimistic about the firm. We measure analyst optimism along three dimensions: long-term growth forecasts, the proportion of analysts who follow the firm and have recommended the stock as "buy" and "strong buy," and the median consensus recommendation score ranging from one (strong sell)

\footnotetext{
${ }^{13}$ Dechow et al. (2011) document that AAER firms have high accruals before the manipulation period and show that $F$ scores are increasing and peak during the manipulation period (see their Figure 3). These results are consistent with AAER firms using "within GAAP" accounting flexibility before resorting to "outside of GAAP" techniques. Our sample differs from Dechow et al.'s (2011) since we require analyst coverage. Analysts cover larger and more successful companies and prior research argues that firms that consistently beat expectations appear to do so via guidance rather than earnings management (e.g., Matsumoto, 2002). Therefore, it is not necessarily the case that AAER firms with analysts' forecasts will have unusual accruals prior to the manipulation period. Thus, our results suggest that firms are likely to be using all available "tools" to meet expectations prior to manipulating earnings.
} 
to five (strong buy). We plot the average time-series of these variables for which the measurement is at the beginning of each year. The graphs are set up in a similar way to those in Figure 2.

Panel A of Figure 3 reports the average long-term growth expectations. The results indicate that for up to three years prior to and during the manipulation period, analysts have higher long-term growth forecasts for AAER firms than for both comparison groups. After the manipulation ends, long-term growth forecasts for AAER firms are similar to those for the population. Panel B presents the proportion of analysts with "buy" and "strong buy" recommendations. The plot indicates that for all-one string AAER firms, the proportion of analysts recommending "buy" peaks in the year prior to manipulation and remains high in the first manipulation year (at around 70 percent). This proportion is higher than the population's (around 60 percent). Finally, Panel $\mathrm{C}$ reports the average recommendation score. The average recommendation score is over " 4 " for AAER firms and declines after manipulation stops. Taken together, the plots suggest that prior to the manipulation period analysts are placing considerable pressure on the firms to show growth and to maintain or increase the stock price. This evidence supports our prediction $P 3$.

We next investigate proxies that are indicative of market pressure from investors to deliver performance. Panel A of Figure 4 reports the average forward price-to-earnings $(P E)$ ratio. The plots indicate that for up to three years prior to and during the manipulation period, AAER firms have higher forward $P E$ ratios. However, after the manipulation period ends, these firms have similar $P E$ ratios to the population. The second proxy is the proportion of shares held by institutional investors. Panel B shows that in the three years prior to the manipulation period, institutional holdings for AAER firms are lower than for the population. AAER firms' institutional ownership, however, is increasing over these three years and there is a fairly large increase at the start of the manipulation period. As manipulation ends, the upward trend in institutional holdings stops. The patterns in these plots suggest that 
manipulating executives are under pressure to deliver earnings to maintain a high valuation as reflected in the $P E$ ratio and to retain institutional investors' interest in their firm.

Table 5 reports more formal statistical comparisons. Note that unlike focusing on the first manipulation year in Figure 3 and 4, we include all manipulation years in Table 5. In addition, we calculate the market pressure variables in Figure 3 and 4 on a firm basis, whereas in Table 5 we measure the same variables on a firm-year basis and at the beginning of each manipulation year. Thus, results in Table 5 are not directly comparable to the plots reported in Figures 3 and 4 . We provide three comparisons: Panel A compares AAER firms to the population, Panel B compares AAER all-one strings to population all-one strings, and Panel C compares AAER firms to the propensity-score-matched nonAAER firms. Since results are similar across all panels, we only provide a detailed discussion of Panel A here. Panel A of Table 5 provides univariate comparisons of analyst and investor pressure proxies between AAER and population firm-year observations at the beginning of each year during the manipulation period. The average long-term growth forecast of 19.59 percent for the AAER sample is significantly higher than the 16.84 percent for the population (t-statistic of 6.06). The average percentage of buy and strong buy recommendations for the AAER sample is 67.37 percent, which is significantly higher than the 56.64 percent for the population (t-statistic of 7.44). The average recommendation score for the AAER sample is also significantly higher than that of the population. For the investor pressure variables, we find that the forward $P E$ ratio for AAER firms at the beginning of each manipulation year is significantly higher than that of the population (40.05 versus 30.78 , t-statistic of 2.70). In addition, the AAER sample has a significantly higher average percentage of institutional ownership than the population (59.22 percent versus 49.36 percent, t-statistic of 7.08). Results are similar for Panel B and C. 
Figure 5 provides corollary evidence related to investor pressure. Skinner and Sloan (2002) document that relative to positive earnings surprises, negative earnings surprises have larger negative stock price reactions for growth firms. Thus, AAER firms that have high PE multiples could suffer more negative stock price consequences for a miss in expectations. Panel A of Figure 5 plots the three-day stock price reaction to the announcement of the manipulated quarterly earnings of AAER all-one strings. For comparison purposes, we provide the stock returns for the population of firms that also beat in all four quarters during a fiscal year. The results indicate that AAER all-one strings, like population firms, earn positive returns at each quarterly earnings announcement of between 0.6 percent and around two percent. Panel B of Figure 5 then reports the stock price reaction when the AAER all-one string firms first miss expectations. For comparative purposes, we also plot the cumulative returns earned during the four beating quarters for each group. Panel B indicates that the average twelve-day (the three-day returns over four quarters) cumulative return is 5.32 percent for AAER firms versus 5.22 percent for the population, and the difference is not statistically significant. In contrast, we find that when the string of positive surprises breaks, AAER firms have an average three-day announcement return of -7.13 percent, which is significantly more negative than the return of -3.67 percent for the population (t-statistic of 1.97). These results suggest that the manipulation delays a negative stock price shock, which is consistent with our hypothesis that managers feel pressure to manipulate earnings to keep beating expectations so as not to disappoint investors.

\subsection{Internal pressure from the $\mathrm{CEO}$}

We next investigate whether executives of AAER firms are under strong internal pressure from the CEO to beat expectations. Similar to Table 5, all variables in Table 6 are measured at the beginning of the fiscal year. The first internal pressure variable is CEO overconfidence (OVERCONFIDENT), an 
indicator variable that equals one if the CEO is overconfident and zero otherwise. Following Schrand and Zechman (2012), managerial overconfidence is present when the natural log of the sum of in-themoney unexercised but exercisable options held by the CEO (opt_unex_exer_est_val + 0.01) is greater than the three-digit SIC industry median. Our results suggest that 58.90 percent of CEOs of AAER firms are overconfident as they appear to delay the exercise of stock options relative to their industry counterparts, while this number is 47.54 percent for the population. The difference is statistically significant with a t-statistic of 2.92 and is consistent with Schrand and Zechman (2012). ${ }^{14}$ We next examine the CEO's personal financial incentives. Following Feng et al. (2011), we measure CEO payfor-performance sensitivity (SENSITIVITY) based on CEO's stock-based compensation. A CEO with equity compensation more sensitive to stock price changes is more likely to be concerned with stock price declines. Consistent with Feng et al. (2011), we find that CEOs of AAER firms have significantly greater pay-for-performance sensitivity than the average CEO in the population (39.10 percent versus 29.84 percent, t-statistic of 5.34).

CEOs also need sufficient power to influence other executives. We examine three proxies for CEO power. The first proxy is CEO pay slice (PAYSLICE), defined as the ratio of CEO's total compensation to the total compensation of the top five executives (e.g., Bebchuk et al., 2011; Feng et al., 2011). A greater pay slice could indicate a more powerful and greedier CEO, who is able to extract more rents from the company, in terms of compensation, than other executives. It could also indicate a CEO who is competitive and concerned with meeting expectations. The results suggest that AAER firms' CEOs have a significantly higher pay slice than the population (46.51 percent versus 40.85 percent, $t$ statistic of 4.75). The second proxy of CEO power is the percentage of independent directors

\footnotetext{
${ }^{14}$ Our sample of AAER firms includes a few companies that were identified by the SEC as having backdated stock options, which are likely to lead mechanically to higher values of OVERCONFIDENT. When we exclude backdating firms from our analysis of overconfidence, untabulated results are weaker but remain statistically significant.
} 
$(I N D B O A R D)$. A lower percentage of independent directors is indicative of a more powerful CEO. Our results suggest that AAER firms have a significantly lower proportion of independent directors than the population (75.75 percent versus 80.32 percent, $t$-statistic of -4.76 ). Our third proxy for CEO power is an indicator variable that equals one when the CEO is also the chairman of the board, and zero otherwise (CEOCHAIR). Our results suggest that AAER firms have a significantly higher incidence of CEO duality than the population (76.69 percent versus 60.93 percent, t-statistic of 4.71). ${ }^{15}$

Panel B of Table 6 compares the internal pressure proxies for AAER all-one strings and population all-one strings. Results are similar to those reported in Panel A. In Panel C, we compare AAER firms to the propensity-score-matched non-AAER firms. We find that the difference in CEO overconfidence is no longer significant and that the difference in CEO pay-for-performance sensitivity becomes weakly significant. This evidence suggests that CEO equity compensation for AAER firms is only weakly different from matched firms and is in line with the mixed results in prior research in which matching reduces significance levels (Armstrong et al., 2010). In summary, the evidence in Panel C suggests that $\mathrm{CEO}$ overconfidence does not explain earnings manipulation, and that equity incentives appear to be less important once we match on firm characteristics.

Overall, the results reported in Table 6 suggest that pay-slice and governance characteristics are important for explaining earnings manipulation, but that equity incentives and stock option exercising behavior are only weakly associated with the likelihood of reporting manipulated earnings.

\subsection{Multivariate analysis}

\footnotetext{
${ }^{15}$ In untabulated tests we investigate the extent to which the CEO is involved in the manipulation and whether the manipulation takes place only at the divisional level by manually checking the original AAER reports. We find that in most cases, CEOs are directly involved in the manipulation. Out of 136 unique AAERs in our sample, only four AAER firms have earnings manipulation confined at the subsidiary level. Since the proportion of subsidiary-confined AAERs is small, we do not distinguish these cases. In addition, even though the CEO is generally not directly involved in subsidiary level manipulation, he/she may still play a part by putting pressure on subsidiaries to perform.
} 
In our multivariate analysis, we seek to better understand whether market pressure from analysts and investors is incrementally significant over the internal pressure CEOs exert on executives in explaining earnings manipulation. In addition, we investigate whether a reputation for beating expectations is subsumed by external market pressure and internal CEO pressure or whether it appears to be an independent determinant of manipulation.

Table 7 reports the results of logistic regressions examining the different sets of motivating factors of "outside of GAAP" earnings manipulation. The dependent variable in these regressions is $A A E R$, which equals one in manipulation years, and zero otherwise. Panel A compares AAER firms to the population, and Panel B compares AAER firms to the propensity-score-matched non-AAER firms. We do not tabulate results focusing on AAER all-one strings and their counterparts, but these results give similar inferences. In Panel A, Regression (1) focuses on the external market pressure variables. Consistent with results in Table 5, our regression results suggest that higher pressure from analysts in the form of high long-term growth forecasts and stock recommendations in the prior year increases the odds of manipulation in the following year. In addition, having a higher valuation premium (as reflected in a forward $P E$ ratio in the highest annual quintile), along with greater institutional holdings, increases the odds of manipulation. The pressure variables are incrementally significant over the firms' use of flexibility within the accounting system (as measured by the annual decile rank of F-score, RANKFSCORE) and other firm characteristics including size, leverage, and profitability improvement (SIZE, LEV, and $\triangle R O A$ ). Regression (2) of Panel A reports the results related to CEO overconfidence, compensation, and power. We find that the CEO variables are all statistically significant in the predicted direction with the exception that the coefficient on CEO overconfidence is significantly negative. In untabulated results we find that OVERCONFIDENT has a 30 percent correlation with SENSITIVITY and that OVERCONFIDENT loads with the correct sign only when SENSITIVITY is excluded from the 
regression. This evidence suggests that the sensitivity of a CEO's equity compensation to stock price is more important than overconfidence in explaining manipulation.

Regression (3) of Panel A examines whether a reputation for consistently beating expectations (BEATPCT $\left.T_{\text {Prior3Y }}\right)$ is incrementally significant over control variables in explaining "outside of GAAP" earnings manipulation. We find that after controlling for the use of accounting flexibility and firm characteristics, the coefficient for BEATPCT $T_{\text {Prior3Y }}$ is significantly positive at 2.992 (z-statistic of 5.61). Regression (4) includes the market pressure and internal pressure variables along with the reputation for beating expectations. The results indicate that CEO power and compensation related incentives remain important in explaining earnings manipulation. The coefficient for the CEO overconfidence proxy continues to have the incorrect sign. More importantly, we document that BEATPCT Prior3Y is incrementally significant (coefficient of 3.133, z-statistic of 4.02) in the presence of both external and internal pressure variables. ${ }^{16}$ This evidence is consistent with the executive team caring about their reputation for beating expectations beyond pressure placed on them by the CEO or the stock market.

Panel B of Table 7 reports the regression results based on AAER firms and the propensity-scorematched non-AAER firms. The results for Regression (1) and (2) are similar to those reported in Panel A with the exception that the coefficient on the CEO overconfidence proxy is now of the predicted sign but insignificant. Thus, after better matching and including other CEO characteristics, overconfidence does not appear to explain manipulation. ${ }^{17}$ The results for Regression (3) and (4) are also similar to those

\footnotetext{
${ }^{16}$ In untabulated tests we replace $B E A T P C T_{\text {Prior3Y }}$ with $B E A T P C T_{\text {Rolling3Y, which measures the percentage of beats over the }}$ past three years, including manipulation years if applicable. Results are very similar to those reported in Table 7.

${ }^{17}$ One possible reason for the weak overconfidence result in our study is that the use of stock options declined in popularity in favor of restricted stock grants after the mandatory expensing of stock options in 2006. In untabulated analysis, we restrict the analysis in Table 6 and 7 to the sample period prior to 2006 and find similar results, suggesting that the results are not driven by the sample period of our study.
} 
reported in Panel A and again they are consistent with the conclusion that a reputation for consistently beating expectations is incrementally significant over market and CEO pressure proxies.

\section{CONCLUSION}

This study examines whether maintaining a reputation for consistently beating analysts' expectations motivates executives to move from "within GAAP" earnings management to "outside of GAAP" earnings manipulation. We use a sample of firms that are subject to SEC enforcement actions to identify "outside of GAAP" earnings manipulation. The benefit of this sample is that we are confident that manipulation did indeed take place, but a limitation of the sample is that the sample size is small, and these firms were "caught" by the SEC and therefore may differ from other firms that engage in manipulation.

We document that manipulating firms are more likely to have consistently beaten analysts' forecasts in the three years prior to the manipulation period. We investigate factors that could motivate executives to manipulate earnings to consistently beat analysts' forecasts. We predict and find that manipulating firms face strong external market pressure to continue the trend of consistently beating expectations. In particular, manipulating firms have relatively high price-earnings ratios for up to three years prior to the manipulation period. Meanwhile, institutional investors are increasing their holdings in these firms, and analysts are making optimistic long-term growth forecasts and predominantly promoting these firms as "buys" and "strong buys." We hypothesize that manipulating firms also face internal pressure from CEOs to deliver performance. Specifically, we investigate proxies for CEO overconfidence, compensation incentives, and power. Our empirical results provide weak and conflicting evidence for the role of CEO overconfidence in explaining earnings manipulation. This result could be attributable to the noise in our proxy which is based on CEOs' not exercising options in an 
optimal manner or the close correlation between our CEO overconfidence proxy and CEO equity-based compensation measures. We also find that manipulating CEOs have more equity-based compensation consistent with CEOs being especially concerned with their firm's stock valuation. Consistent with prior research, we find that AAER firms have less independent board representation, their CEOs are more likely to be the chairman of the board and receive a larger slice of the compensation pool, suggesting that manipulating CEOs have more power over their boards to set the strategic direction of the company and potentially lead the firms to be overly focused on beating analysts' expectations.

Our study raises opportunities for future research. We document that manipulating firms consistently beat analysts' expectations prior to manipulation. One avenue for future research is to examine how companies deal with missing analysts' forecasts. For instance, do firms with better governance miss analysts' forecasts more frequently and avoid playing the "expectations" game altogether? Are managers penalized less for missing earnings expectations in better governed firms or does consistently beating earnings expectations reap strong personal benefits for top executives? A second avenue for future research is to better understand the role of guidance and how it interacts with manipulation. How does guidance change before and after the manipulation period? Are certain managers particularly concerned with losing credibility by guiding down and so view manipulation as a less costly alternative? We hope that future research will endeavor to answer some of these questions. 


\section{REFERENCES}

Allen, E., P. Dechow, D. Pope, and G. Wu. 2016. Reference-dependent preferences: evidence from marathon runners. Management Science 63 (6): 1657-1672.

Allen, E., C. Larson, and R. Sloan. 2013. Accrual reversals, earnings and stock returns. Journal of Accounting and Economics 56 (1): 113-255.

Armstrong, C., A. Jagolinzer, and D. Larcker. 2010. Chief executive officer equity incentive and accounting irregularities. Journal of Accounting Research (48): 225-271.

Badertscher, B. 2011. Overvaluation and the choice of alternative earnings management mechanisms. Accounting Review 86 (5): 1491-1518.

Barth, M., J. Elliott, and M. Finn. 1999. Market rewards associated with patterns of increasing earnings. Journal of Accounting Research 37 (2): 387-413.

Bartov, E., D. Givoly, and C. Hayn. 2002. The rewards to meeting or beating earnings expectations. Journal of Accounting and Economics 33 (2): 173-204.

Beasley, M. 1996. An empirical analysis of the relation between the board of director composition and financial statement fraud. Accounting Review 71 (4): 443-465.

Bebchuk, L., K. Cremers, and U. Peyer. 2011. The CEO pay slice. Journal of Financial Economics 102 (1): 199-221.

Black, E., T. Christensen, T. Joo, and R. Schmardebeck. 2017. The relation between earnings management and non-GAAP reporting. Contemporary Accounting Research. 34 (2): 750-782.

Bushee, B., and G. Miller. 2012. Investor relations, firm visibility, and investor following. Accounting Review 87 (3): 867-897.

Bushee, B., and C. Noe. 2000. Corporate disclosure practices, institutional investors, and stock return volatility. Journal of Accounting Research 38: 171-207.

Cheng, Q., and T. Warfield. 2005. Equity incentives and earnings management. Accounting Review 80 (2): 441-476.

Christensen, T., A. Huffman, and M. Lewis-Western. 2017. Earnings management proxies: prudent business decisions or earnings manipulation? Working paper. Available at: https://papers.ssrn.com/sol3/papers.cfm?abstract_id=2793838

Dechow, P., W. Ge, C. Larson, and R. Sloan. 2011. Predicting material accounting misstatements. Contemporary Accounting Research 28 (1): 17-82.

Dechow, P., R. Sloan, and A. Sweeney. 1996. Causes and consequences of earnings manipulation: an analysis of firms subject to enforcement actions by the SEC. Contemporary Accounting Research 13 (1): 1-36.

Dechow, P. and D. Skinner. 2000. Earnings Management: Reconciling the Views of Accounting Academics, Practitioners, and Regulators. Accounting Horizons 14 (2): 235-250.

DeFond, M., and C. Park. 2001. The reversal of abnormal accruals and the market valuation of earnings surprises. Accounting Review 76 (3): 375-404.

Doyle, J., J. Jennings and M. Soliman. 2013. Do managers define non-GAAP earnings to meet or beat analyst forecasts? Journal of Accounting and Economics, 56, 40-56.

Efendi, J., A. Srivastava, and E. Swanson. 2007. Why do corporate managers misstate financial statements? The role of in-the-money options and other incentives. Journal of Financial Economics 85 (3): 667-708.

Fama, E., and K. French. 1997. Industry costs of equity. Journal of Financial Economics 43 (2): 153193. 
Feng, M., W. Ge, S. Luo, and T. Shevlin. 2011. Why do CFOs become involved in material accounting manipulations? Journal of Accounting and Economics 51 (1-2): 21-36.

Graham, J., C. Harvey, and S. Rajgopal. 2005. The economic implications of corporate financial reporting. Journal of Accounting and Economics 40 (1): 3-73.

Jensen, M. 2005. Agency costs of overvalued equity. Financial Management 34 (1): 5-19.

Jiang, J., K. Petroni, and I. Wang. 2010. CFOs and CEOs: who has the most influence on earnings management. Journal of Financial Economics 96 (3): 513-526.

Kasznik, R. and M. McNichols. 2002. Does meeting earnings expectations matter? Evidence from analyst forecast revisions and share prices. Journal of Accounting Research 40 (3): 737-759.

Lehavy R. and R. Sloan. 2008. Investor recognition and stock returns. Review of Accounting Studies 13 (2-3): 327-361.

Liu, X. 2016. Corruption culture and corporate misconduct. Journal of Financial Economics 122 (2): 307-327.

Malmendier, U., and G. Tate. 2005. CEO overconfidence and corporate investment. Journal of Finance 60 (6): 2661-2700.

Matsumoto, D. 2002. Management's incentives to avoid negative earnings surprises. Accounting Review 77 (3): 483-514.

Merton, R. 1987. A simple model of capital market equilibrium with incomplete information. Journal of Finance 42 (3): 483-510.

Mikhail, M., B. Walther, and R. Willis. 1999. Does forecast accuracy matter to security analysts? Accounting Review 74 (2): 185-200.

Moore, D., and P. Healy. 2008. The trouble with overconfidence. Psychological Review 115 (2): 502517.

Myers, J., L. Myers, and D. Skinner. 2007. Earnings momentum and earnings management. Journal of Accounting, Auditing and Finance 22 (2): 249-284.

Rogers, J., and P. Stocken. 2005. Credibility of management forecasts. Accounting Review 80 (4): 12331260.

Schrand, C., and S. Zechman. 2012. Executive overconfidence and the slippery slope to financial misreporting. Journal of Accounting and Economics 53 (1): 311-329.

Securities and Exchange Commission (SEC). 2005. Accounting and auditing enforcement release No. 2232. Available at: http://www.sec.gov/litigation/admin/33-8569.pdf.

Skinner, D., and R. Sloan. 2002. Earnings surprises, growth expectations, and stock returns or don't let an earnings torpedo sink your portfolio. Review of Accounting Studies 7 (2-3): 289-312.

Soltes, E. 2016. Why they do it: inside the mind of the white-collar criminal. PublicAffairs Books. ISBN-13: 9781610395373.

Tversky, A., and D. Kahneman. 1991. Loss aversion in riskless choice: a reference-dependent model. Quarterly Journal of Economics 106 (4): 1039-1061.

Williams, P. 1996. The relation between a prior earnings forecast by management and analyst response to a current management forecast. Accounting Review 71 (1): 103-113. 


\section{APPENDIX A}

\section{Coca Cola and Its Incentive to Report Positive Earnings Surprises}

The discussion below is extracted from SEC's Accounting and Auditing Enforcement Releases

(No. 2232) for Coca Cola.

"From 1990 through 1996, Coca-Cola consistently met or exceeded earnings expectations while achieving a compound annual earnings per share growth rate of 18.3 percent - more than twice the average growth rate of the S\&P 500. Coca-Cola's superior earnings performance resulted in its common stock trading at a price to earnings multiple ("P/E Ratio") of 38.1 by the end of 1996 , as compared to the S\&P 500's P/E Ratio of 20.8 .

In the mid-1990s, Coca-Cola began experiencing increased competition and more difficult economic environments. Nevertheless, Coca-Cola publicly maintained between 1996 and 1999 that it expected its earnings per share to continue to grow between 15 percent and 20 percent annually. At or near the end of each reporting period between 1997 and 1999, Coca-Cola, through its officers and employees implemented a "channel stuffing" practice in Japan known as "gallon pushing." In connection with this practice, CCJC asked bottlers in Japan to make additional purchases of concentrate for the purpose of generating revenue to meet both annual business plan and earnings targets. The income generated by gallon pushing in Japan was the difference between Coca-Cola meeting or missing analysts' consensus or modified consensus earnings estimates for 8 out of 12 quarters from 1997 through 1999."

The Coca Cola channel stuffing example nicely illustrates the incentives and possible implementation of financial misstatement in the service of consistently beating earnings benchmarks. 


\section{APPENDIX B \\ Variable Definitions}

Variables Definitions $\begin{array}{ll}A A E R_{\text {it }} & \text { Indicator variable equals one if the string observation is an AAER firm, } \\ \text { and zero otherwise. }\end{array}$

Reputation for consistently beating analysts' expectations

BEATPCT $T_{\text {Prior } 3 Y} \quad$ Percentage of quarters that a firm beats (meets or beats) the median analyst consensus EPS forecast in the three years prior to the manipulation period.

BEATPCT $T_{\text {During }} \quad$ Percentage of quarters that a firm beats (meets or beats) the median analyst consensus EPS forecast during the manipulation period.

Indicator variable equals one if the firm beats (meets or beats) the median

all-one string analyst consensus EPS forecast in all four quarters of a fiscal year, and zero otherwise.

Market pressure from analysts

$L T G_{i t-1}$

$H_{I G H T G}$ it -1

$B U Y P C T_{i t-1}$

$H_{I G H B U Y P C T_{i t-1}}$

$R E C M D_{i t-1}$

STRONGBUY $Y_{i t-1}$

SURPRISE_EPS

SURPRISE_\%

Market pressure from investors

The median analyst consensus long-term growth forecast. We take the most recent consensus forecast made after the end of fiscal year $t-1$ and before the first earnings announcement of fiscal year $t$.

Indicator variable equals one if the median analyst consensus long-term growth forecast is in the highest annual quintile, and zero otherwise. Percentage of analysts giving buy and strong buy recommendations, measured as of the most recent IBES summary date after the end of fiscal year $t-1$ and before the first earnings announcement of fiscal year $t$. Indicator variable equals one if the percentage of analysts giving buy and strong buy recommendations is in the highest annual quintile, and zero otherwise.

The median analyst consensus stock recommendation which ranges from one to five. A rank of one represents a strong sell recommendation and a rank of five represents a strong buy recommendation. We take the most recent consensus recommendation made after the end of fiscal year $t-1$ and before the first earnings announcement of fiscal year $t$.

Indicator variable equals one if analysts give consensus strong buy stock recommendation, and zero otherwise.

The difference between actual quarterly EPS and the median analyst consensus quarterly EPS forecast. We take the most recent consensus forecast made before each quarterly earnings announcement.

The difference between actual quarterly EPS and the median analyst consensus quarterly EPS forecast, scaled by the absolute value of actual quarterly EPS. We take the most recent consensus forecast made before each quarterly earnings announcement.

Forward price-to-earnings ratio measured as the stock price at the end of $P E_{i t-1}$ fiscal year $t-1$ divided by the first median analyst consensus annual EPS forecast for fiscal year $t$ made following the annual earnings 
$H I G H P E_{i t-1}$

IHELD $_{i t-1}$

RANKIHELD $D_{i t-1}$

CEO overconfidence

OVERCONFIDENT $T_{i t-1}$

CEO compensation

SENSITIVITY $_{i t-1}$

CEO power

PAYSLICE $_{i t-1}$

INDBOARD $D_{i t-1}$

RANKINDBOARD $_{i t-1}$

CEOCHAIR $_{i t-1}$

$\underline{\text { Accounting flexibility }}$

RANKFSCORE $E_{i t}$

$W C A C C_{i t}$

$T A C C_{i t}$

Other firm characteristics

$S I Z E_{i t-1}$

$B T M_{i t-1}$

$L E V_{i t-1}$

$\triangle R O A_{i t-1}$ announcement.

Indicator variable equals one if the $P E$ ratio is in the highest annual quintile, and zero otherwise.

Percentage of institutional holdings measured as the number of shares held by $13-\mathrm{F}$ institutional investors as a percentage of the total shares outstanding as of the latest report date before the end of fiscal year $t-1$.

Annual quintile rank based on $I H E L D_{i t-1}$.

Indicator variable equals one if the CEO is overconfident, and zero otherwise. Managerial overconfidence is present if the natural log of the sum of in-the-money unexercised exercisable options held by the CEO (opt_unex_exer_est_val +0.01 from ExecuComp) is greater than the threedigit SIC industry median.

CEO's pay-for-performance sensitivity, following Feng et al. (2011).

CEO pay slice measured as the ratio of CEO's total compensation to the total compensation of the top five executives.

Percentage of independent directors from RiskMetrics.

Annual quintile rank based on INDBOARD $D_{i t-1}$.

Indicator variable equals one if the CEO also serves as the chairman of the board, and zero otherwise.

Annual decile rank of F-score, following Dechow et al. (2011).

Working capital accruals measured as the change in non-cash current assets minus the change in current liabilities net of short-term debt, scaled by beginning total assets.

Total accruals measured as earnings before extraordinary items and discontinued operations taken from the statement of cash flow minus operating cash flows minus investing cash flows, scaled by beginning total assets.

Firm size measured as the natural log of total assets.

Book-to-market ratio measured as common equity divided by market value of equity.

Leverage measured as total liabilities over total assets.

Change in return-on-assets measured as the increase in the ratio of income before extraordinary items to average total assets. 
EXHIBIT 1

Framework of Consistently Beating Analysts' EPS Forecasts and Earnings Manipulation

Panel A: Economic growth and consistently beating analysts' EPS forecasts.

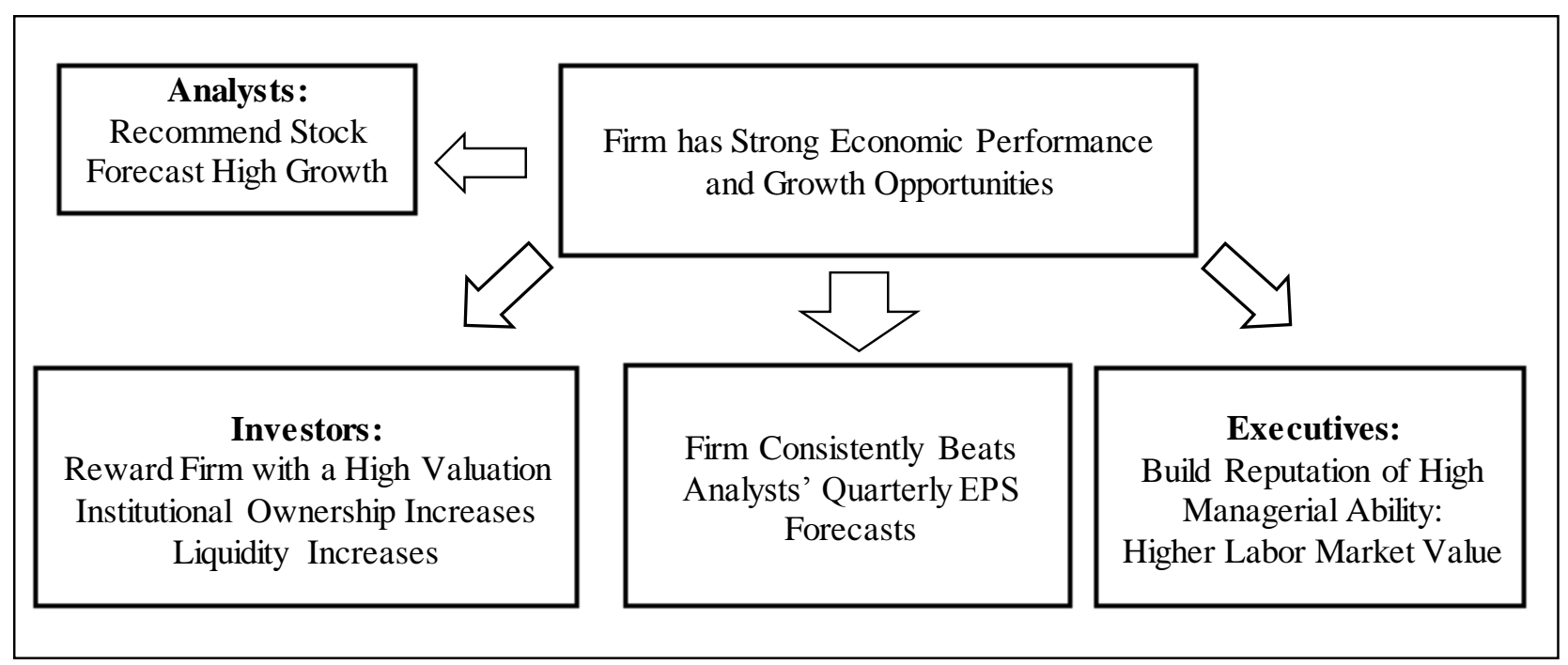

Panel B: Impact of market pressure and CEO pressure on incentive to manipulate earnings.

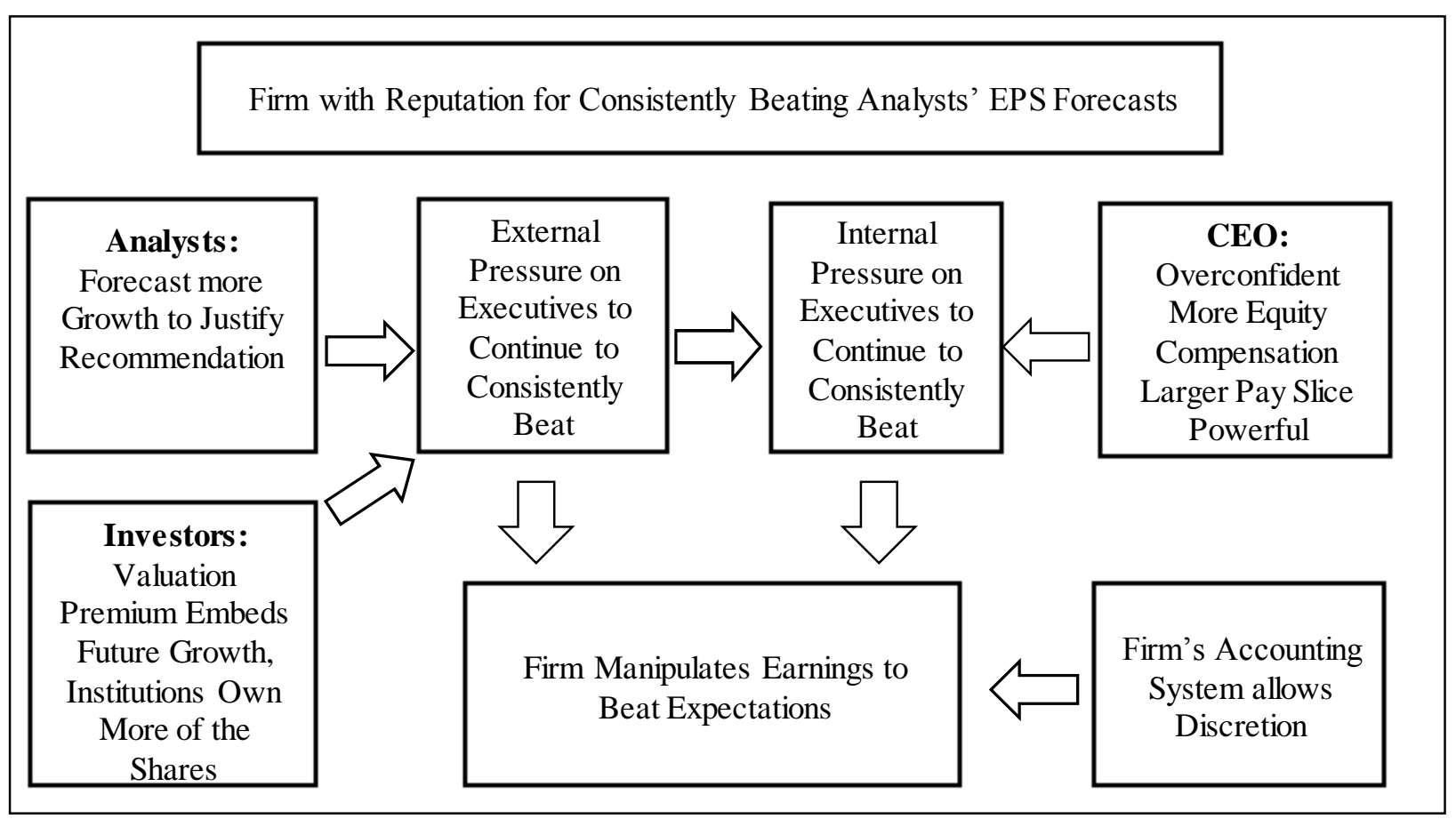




\section{EXHIBIT 2}

String Construction

\section{Panel A: String example of AAER firm Coca-Cola Company, Ltd.}

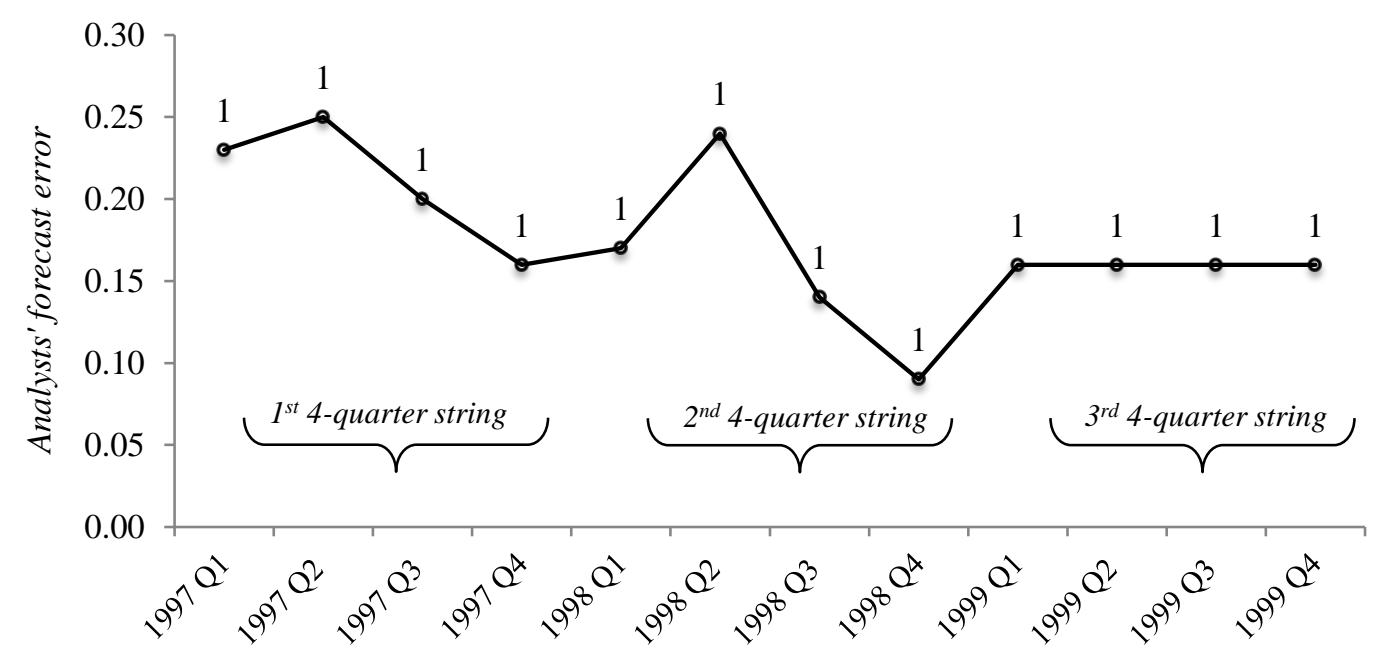

Panel B: String example of propensity-score matched non-AAER firm Heinz.

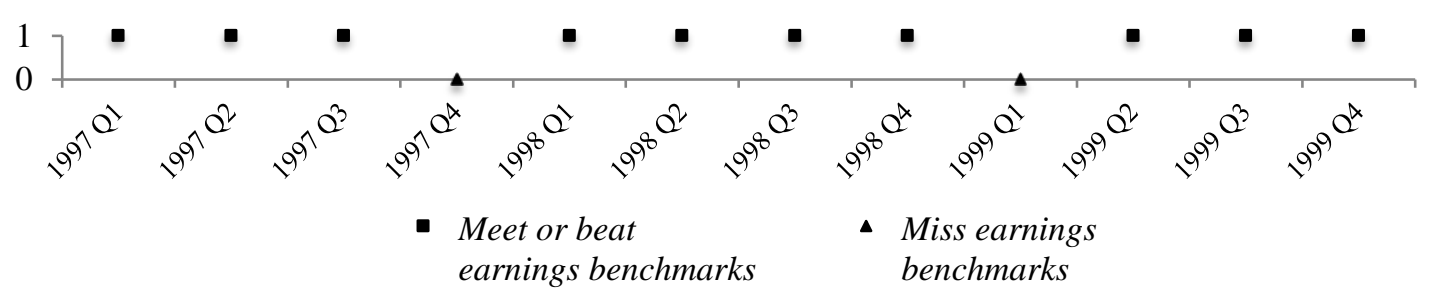

Panel C: Construction of string observations without overlapping quarters.

\begin{tabular}{|c|c|c|}
\hline \multirow[b]{2}{*}{ String observations } & \multicolumn{2}{|c|}{ Time periods and string permutations } \\
\hline & $\begin{array}{c}1997 \text { Q1 - 1997 Q4 } \\
(1,1,1,0)\end{array}$ & $\begin{array}{c}1999 \mathrm{Q} 1-1999 \mathrm{Q} 4 \\
(0,1,1,1)\end{array}$ \\
\hline \multicolumn{3}{|c|}{$\begin{array}{l}\text { Panel A presents Coca-Cola's earnings strings during the manipulation period from } 1997 \text { to } 1999 \text {. A } \\
\text { fiscal quarter receives a "1" for meeting or beating the median analyst consensus forecast and a " } 0 \text { " for } \\
\text { missing the median analyst consensus forecast. The forecast error is calculated as the difference between } \\
\text { actual EPS and the most recent median analyst consensus EPS forecast before earnings announcements } \\
\text { from IBES. Coca-Cola's alleged manipulation period from } 1997 \text { to } 1999 \text { contributes three string } \\
\text { observations to our AAER sample. Panel B presents the earnings string for the matched non-AAER firm } \\
\text { Heinz from } 1997 \text { to 1999. Panel C illustrates our construction of string observations for Heinz. }\end{array}$} \\
\hline
\end{tabular}


FIGURE 1

Time-Series Comparison of Beating Patterns between AAER Firms and the Population

\section{Panel A: Proportion of beats for the AAER sample and the population.}

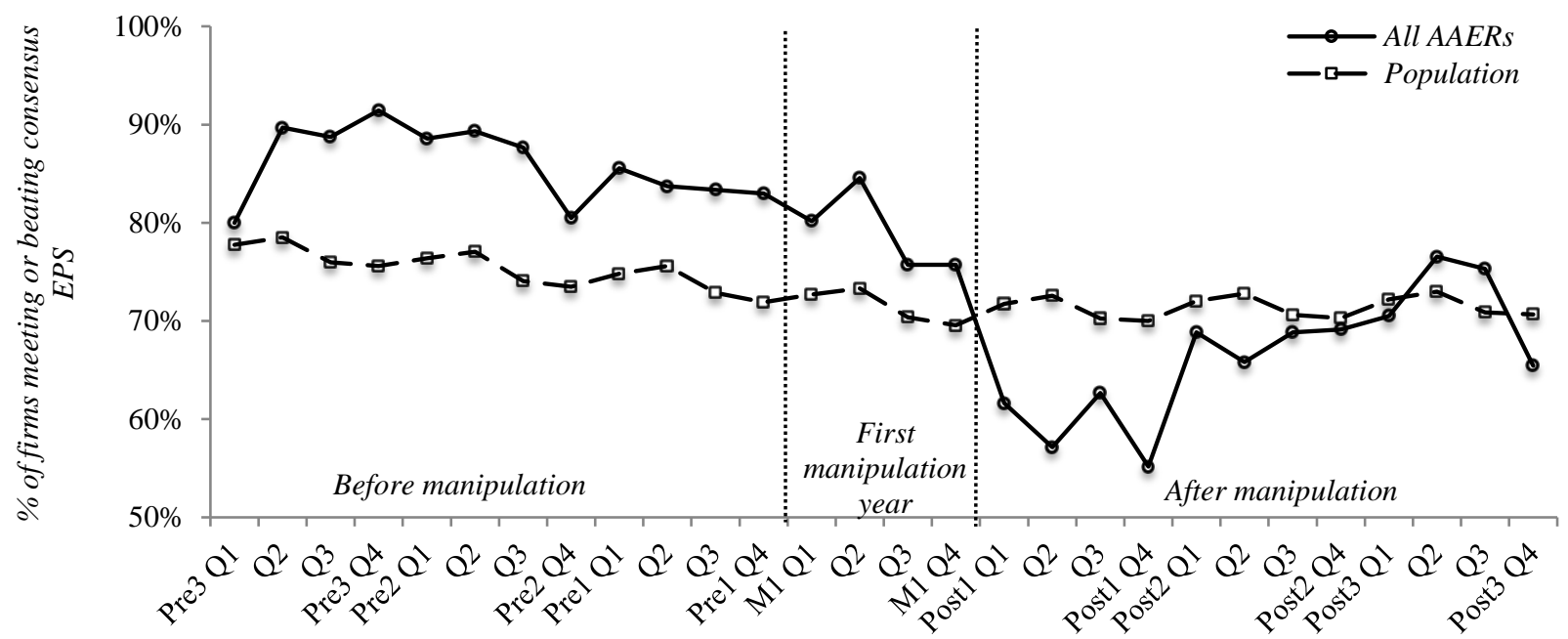

Panel B: Proportion of beats for all-one string AAER firms and the population all-one strings.

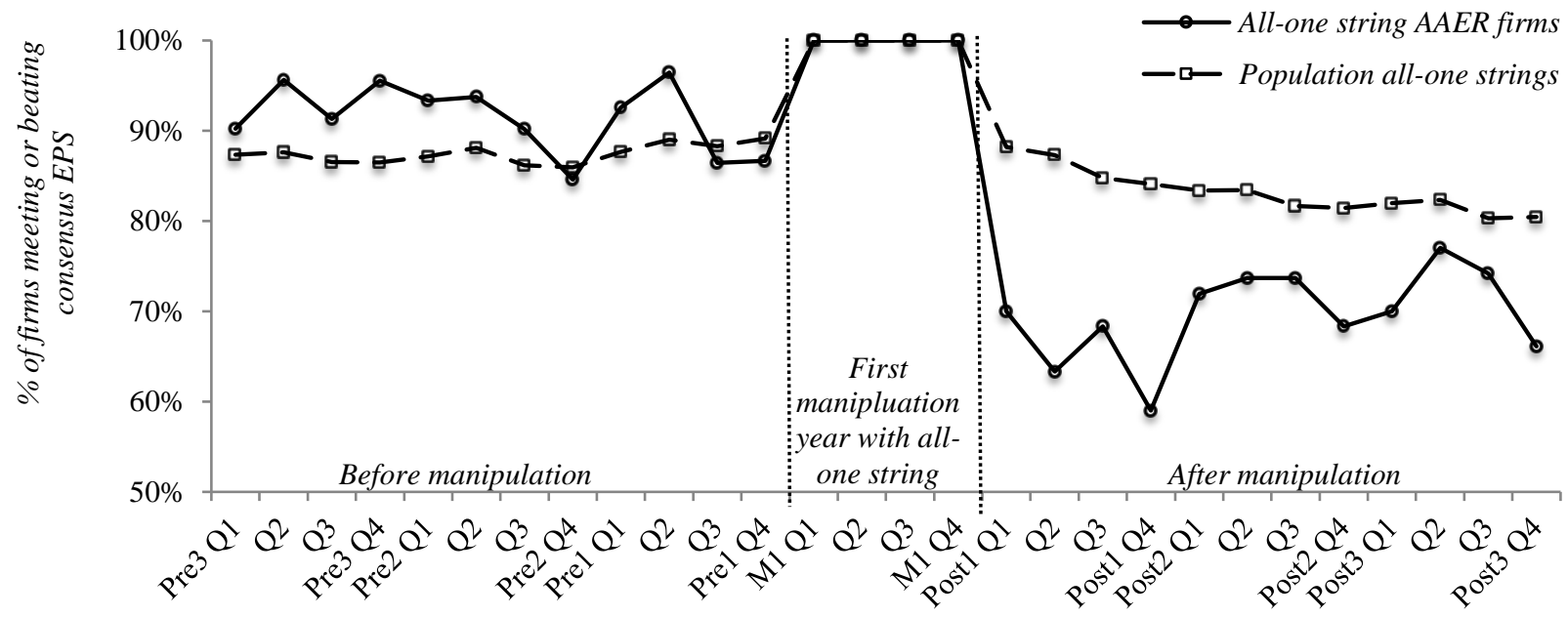

Panel A of this figure presents the time-series proportions of firm-quarter observations meeting or beating analysts' forecasts for 136 AAER firms and the population. Panel B focuses on the subsample of 85 all-one string AAER firms (i.e., AAER firms with at least one all-one string during the manipulation period) and the population all-one strings. When a firm beats the median analyst consensus forecast in all four quarters of a fiscal year, we term it an all-one string. Year $M 1$ is the first fiscal year of manipulation for Panel A. Year $M 1$ is the first fiscal year that the AAER firm achieves an all-one string during the manipulation period for Panel B. We drop the remaining manipulation years for ease of exposition as AAER firms have different manipulation lengths. Year Pre1, Pre2, and Pre3 are the three years immediately prior to the manipulation period. Year Post1, Post2, and Post3 are the three years immediately following the manipulation period. We determine the timeline of variable measurement for the population as follows. Assuming that an AAER firm's first manipulation year is 2000, we use all non-AAER firms as of year 2000 as the AAER firm's year-matched population. We then move backward from 2000 to determine year Prel, 
year Pre2, and year Pre3, and move forward from 2000 to determine year Post1, year Post2, and year Post3 for the population. 
FIGURE 2

Time-Series Comparison of Accruals as a Proxy for Accounting Flexibility between AAER Firms and the Population

Panel A: Working capital accruals.
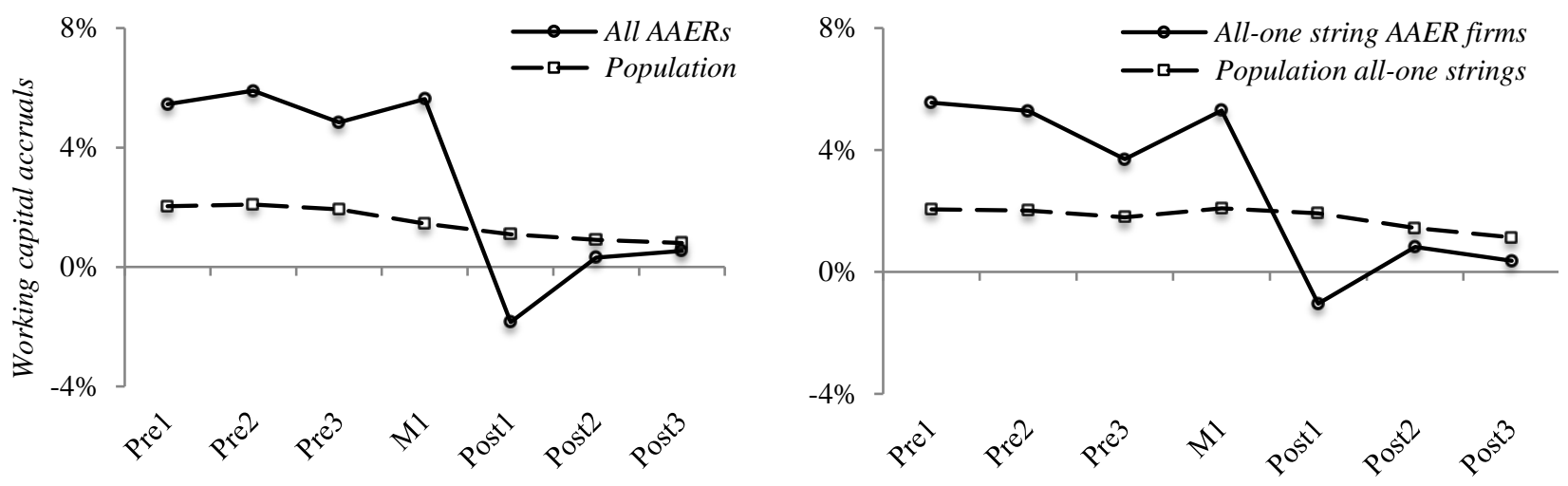

Panel B: Total accruals.
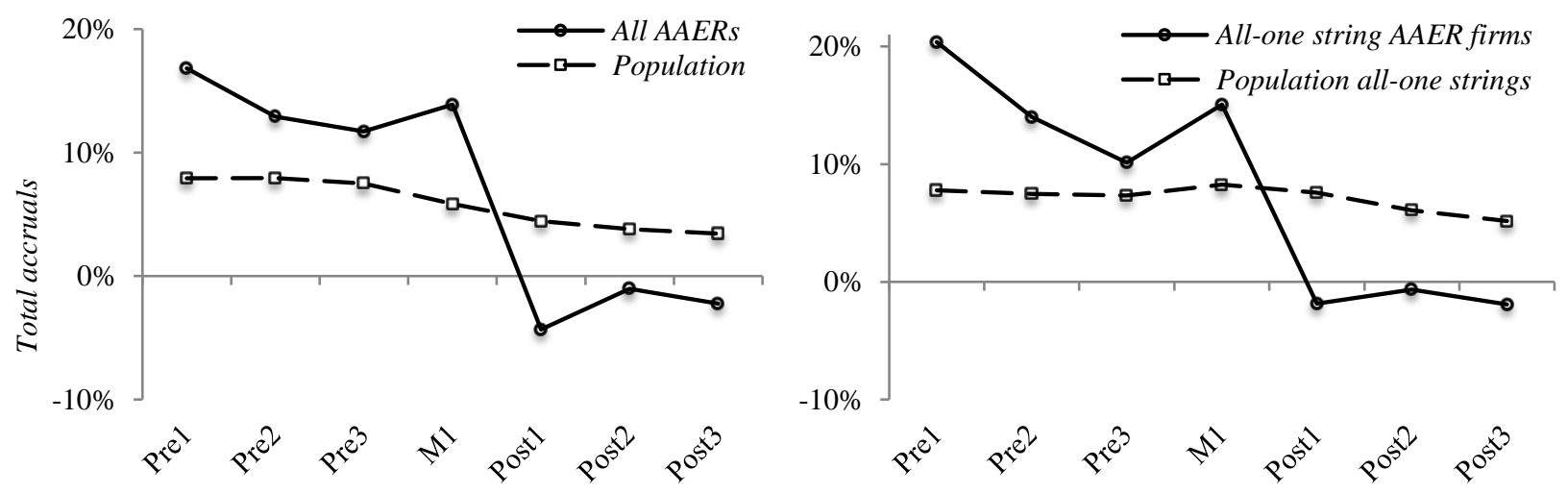

This figure presents the time-series comparison of accruals as a proxy for accounting flexibility between 119 non-financial AAER firms and the population, and between the subsample of 80 non-financial all-one string AAER firms (i.e., AAER firms with at least one all-one string during the manipulation period) and the population all-one strings. Panel A plots the average working capital accruals (WCACC). Panel B plots the average total accruals (TACC). Year $M I$ is the first fiscal year of manipulation for the left plot for each panel. Year $M 1$ is the first fiscal year that an AAER firm achieves an all-one string during the manipulation period for the right plot for each panel. We drop the remaining manipulation years for ease of exposition as AAER firms have different manipulation lengths. Year Pre1, Pre2, and Pre3 are the three years immediately prior to the manipulation period. Year Post1, Post 2 , and Post 3 are the three years immediately following the manipulation period. We determine the timeline of variable measurement for the population as follows. Assuming that an AAER firm's first manipulation year is 2000, we use all nonAAER firms as of year 2000 as the AAER firm's year-matched population. We then move backward from 2000 to determine year Pre1, year Pre2, and year Pre3, and move forward from 2000 to determine year Post1, year Post2, and year Post 3 for the population. 
FIGURE 3

Time-Series Comparison of Market Pressure from Analysts between AAER Firms and the Population

Panel A: Analysts' long-term growth forecasts.
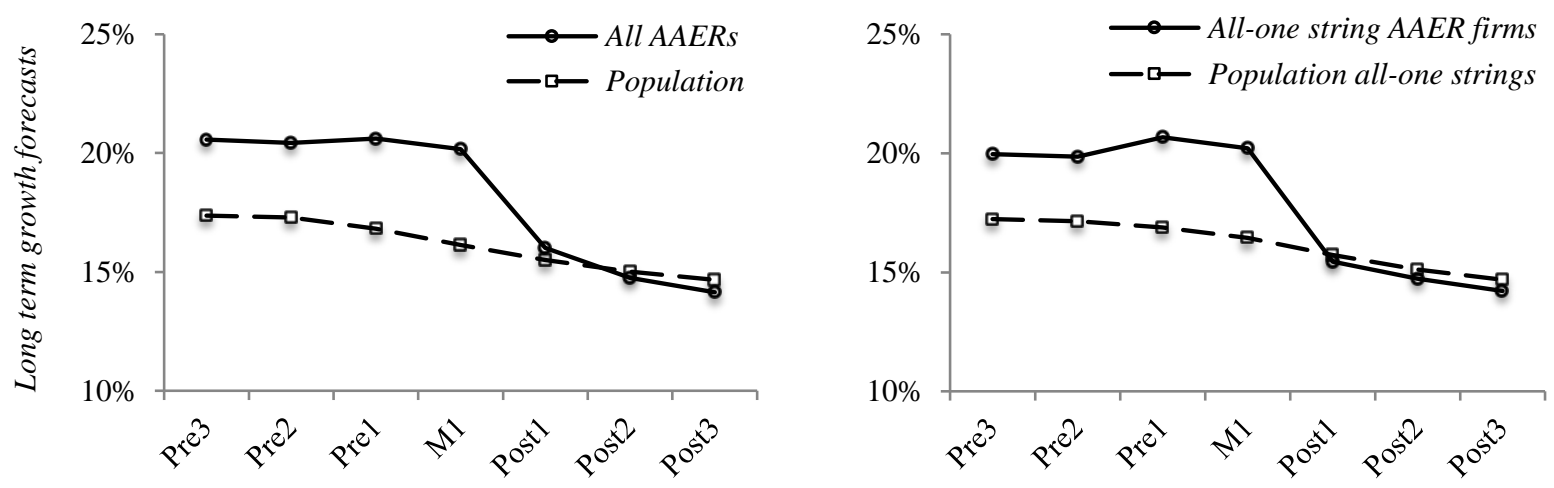

Panel B: Percentage of analysts giving buy and strong buy recommendations.
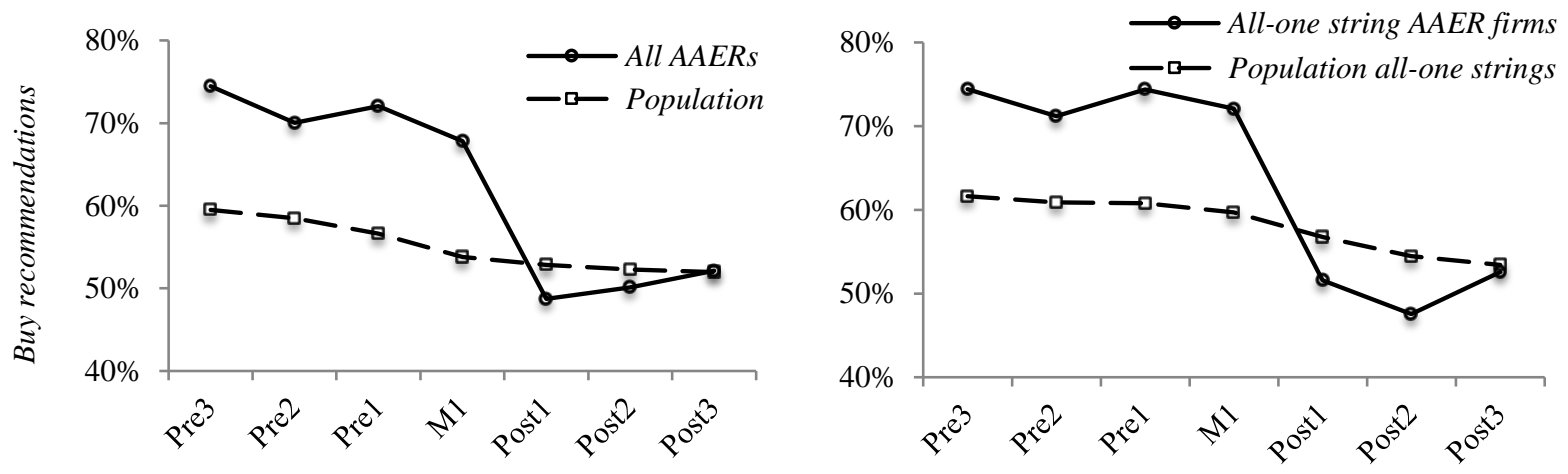

Panel C: Consensus stock recommendation.
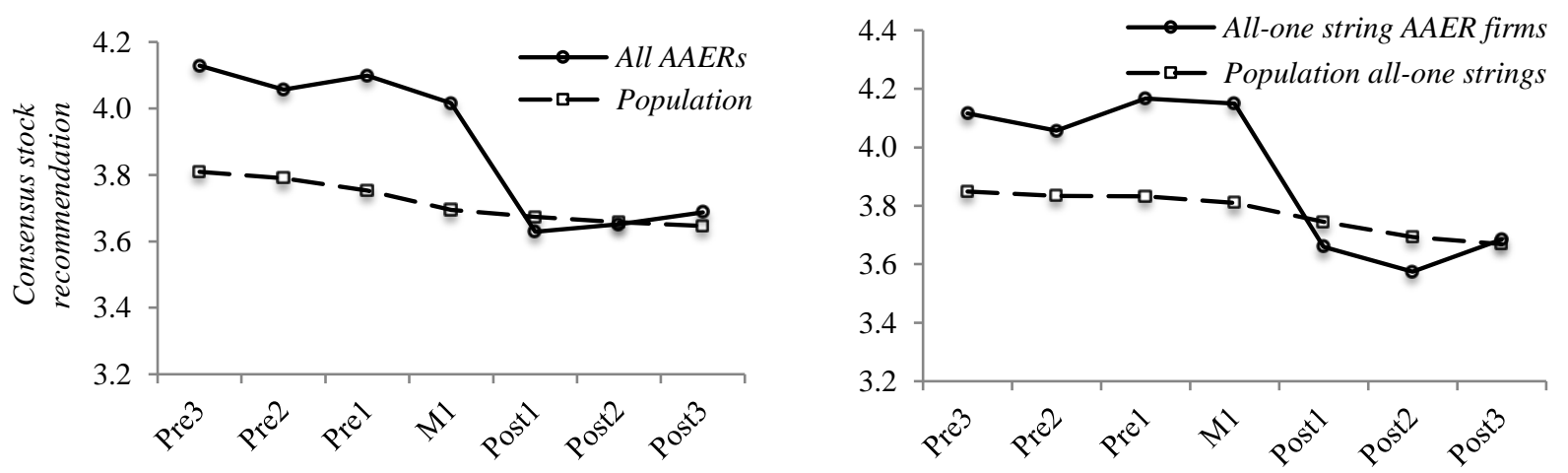


\section{FIGURE 3 (continued)}

This figure presents the time-series comparison of market pressure from analysts between 136 AAER firms and the population, and between the subsample of 85 all-one string AAER firms (i.e., AAER firms with at least one all-one string during the manipulation period) and the population all-one strings. Panel A plots the average analysts' long-term growth forecasts $(L T G)$. Panel B plots the average percentage of analysts giving buy and strong buy recommendations (BUYPCT). Panel $\mathrm{C}$ plots the average consensus stock recommendation $(R E C M D)$. Year $M 1$ is the first fiscal year of manipulation for the left plot for each panel. Year $M 1$ is the first fiscal year that an AAER firm achieves an all-one string during the manipulation period for the right plot for each panel. We drop the remaining manipulation years for ease of exposition as AAER firms have different manipulation lengths. Year Pre1, Pre2, and Pre3 are the three years immediately prior to the manipulation period. Year Post1, Post2, and Post 3 are the three years immediately following the manipulation period. We determine the timeline of variable measurement for the population as follows. Assuming that an AAER firm's first manipulation year is 2000, we use all nonAAER firms as of year 2000 as the AAER firm's year-matched population. We then move backward from 2000 to determine year Pre1, year Pre2, and year Pre3, and move forward from 2000 to determine year Post1, year Post2, and year Post 3 for the population. 
FIGURE 4

Time-Series Comparison of Market Pressure from Investors between AAER Firms and the Population

\section{Panel A: Forward P/E ratio.}
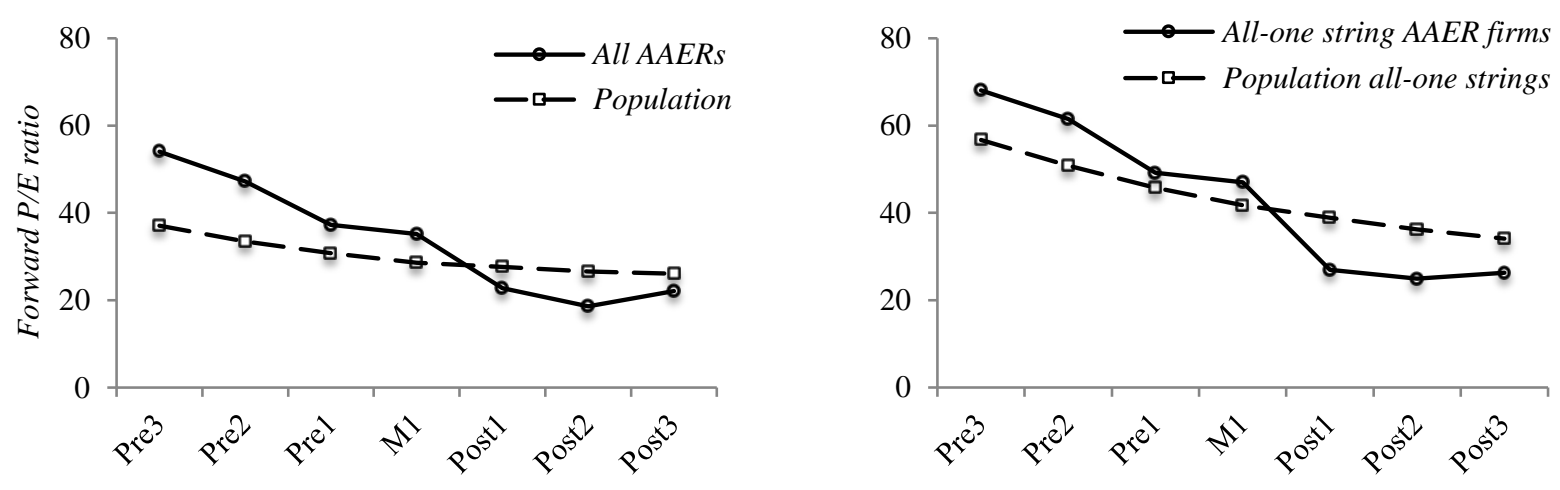

Panel B: Percentage of institutional holdings.
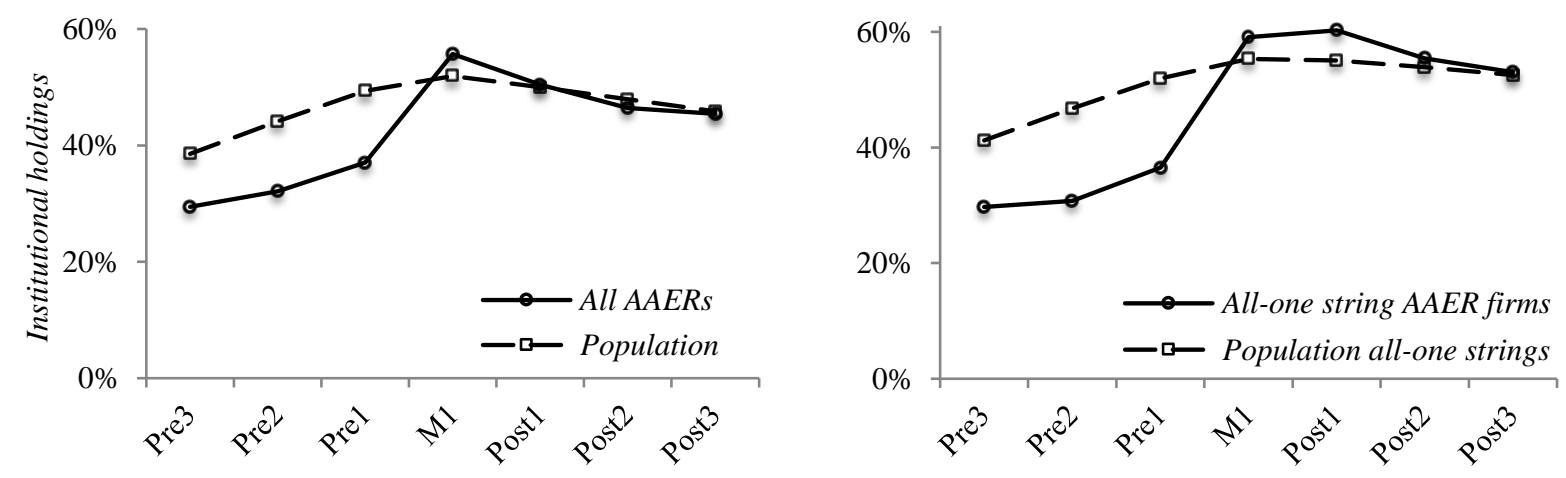

This figure presents the time-series comparison of market pressure from investors between 136 AAER firms and the population, and between the subsample of 85 all-one string AAER firms (i.e., AAER firms with at least one all-one string during the manipulation period) and the population all-one strings. Panel A plots the average forward price-to-earnings ratio $(P E)$. Panel B plots the average percentage of institutional holdings (IHELD). Year $M 1$ is the first fiscal year of manipulation for the left plot for each panel. Year $M 1$ is the first fiscal year that an AAER firm achieves an all-one string during the manipulation period for the right plot for each panel. We drop the remaining manipulation years for ease of exposition as AAER firms have different manipulation lengths. Year Pre1, Pre2, and Pre3 are the three years immediately prior to the manipulation period. Year Post1, Post2, and Post 3 are the three years immediately following the manipulation period. We determine the timeline of variable measurement for the population as follows. Assuming that an AAER firm's first manipulation year is 2000, we use all nonAAER firms as of year 2000 as the AAER firm's year-matched population. We then move backward from 2000 to determine year Pre1, year Pre2, and year Pre3, and move forward from 2000 to determine year Post1, year Post2, and year Post 3 for the population. 
FIGURE 5

Stock Market Response to Earnings String and Its Break around Earnings Announcements

Panel A: Stock market response to quarterly earnings beats.

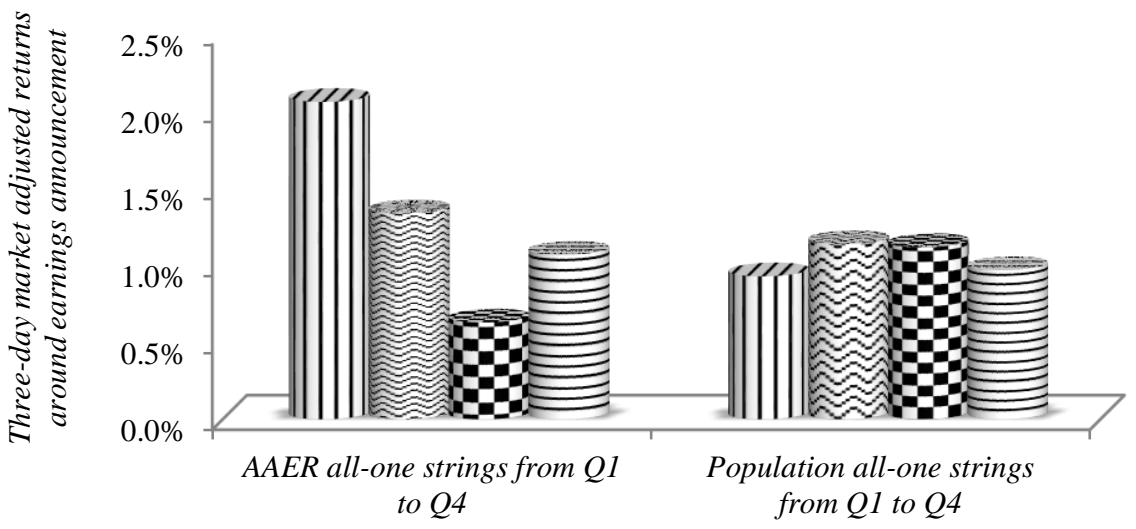

Panel B: Cumulative stock market response to earnings string and its break.

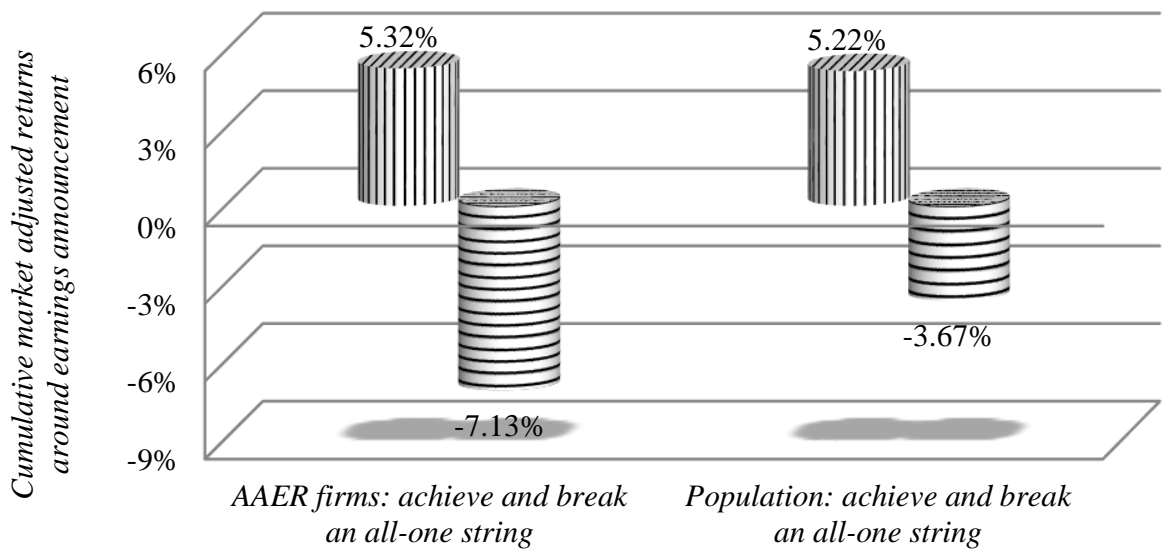

This figure presents the positive stock market response to achieving all-one strings and the negative stock market response to breaking all-one strings. Panel A reports the three-day market adjusted return measured as the raw return less the CRSP value-weighted index around the earnings announcements for each quarter during the four-quarter string period. We measure the string-achievement response in Panel $\mathrm{B}$ by cumulating the four three-day returns over the string period (12-day cumulative return). We measure string-break response as the three-day market adjusted earnings announcement return of the first quarter when the all-one string breaks. Panel B compares the string-achievement response to the string-break response. The t-tests suggest that (1) the string-achievement and the string-break responses are both significantly different from zero, and (2) the string-break response of AAER firms is significantly lower than that of the population. 


\section{TABLE 1}

\section{Sample Selection}

Panel A: AAER sample.

\begin{tabular}{lc}
\hline & \# AAERs \\
\hline AAERs issued from May 1982 to September 2013 involving specific firms & 3,323 \\
Less: & $(1,985)$ \\
Redundant AAERs related to the same firm and incident & $(401)$ \\
AAERs unrelated to financial statement fraud, such as audit failure, bribes, & $(193)$ \\
$\quad$ and disclosure issues & $(423)$ \\
AAERs with no Compustat identifier, gvkey & 321 \\
AAERs with no IBES coverage during the manipulation period & \# firm-year observations \\
Unique AAER firms & 954 \\
\hline $\begin{array}{l}\text { AAER firm-year observations with IBES coverage } \\
\text { Less: }\end{array}$ & $(334)$ \\
Observations without a complete four-quarter fiscal year of misstatement \\
Observations with missing financial data & $(228)$ \\
\hline $\begin{array}{l}\text { Final sample of AAER firm-year observations from 1985 to 2010 } \\
\text { Final sample of unique AAER firms }\end{array}$ & 392 \\
\hline Panel B: Population. & 136 \\
\hline $\begin{array}{l}\text { Firms receiving SEC AAERs } \\
\text { Observations with missing financial data }\end{array}$ & 52,724 \\
\hline Final population from 1985 to 2010 & $(3,034)$ \\
\hline
\end{tabular}


TABLE 1 (continued)

Panel C: Comparison between AAER sample and the propensity-score-matched non-AAER sample.

\begin{tabular}{|c|c|c|c|c|c|c|}
\hline & \multicolumn{2}{|c|}{$\begin{array}{l}\text { AAER sample } \\
\quad(\mathrm{N}=392)\end{array}$} & \multicolumn{2}{|c|}{$\begin{array}{c}\text { One-to-one propensity- } \\
\text { score-matched non-AAER } \\
(\mathrm{N}=392)\end{array}$} & \multicolumn{2}{|c|}{$\begin{array}{c}\text { AAER - Matched non- } \\
\text { AAER }\end{array}$} \\
\hline & Mean & Median & Mean & Median & Mean diff. & t-statistic \\
\hline$S I Z E_{i t-1}$ & 7.04 & 6.65 & 6.91 & 6.81 & 0.13 & 0.92 \\
\hline$B T M_{i t-1}$ & 0.45 & 0.35 & 0.45 & 0.36 & 0.00 & -0.12 \\
\hline$L E V_{i t-1}$ & 0.50 & 0.50 & 0.47 & 0.45 & 0.03 & 1.65 \\
\hline$\Delta R O A_{i t-1}$ & 0.00 & 0.00 & 0.00 & 0.00 & -0.01 & -0.71 \\
\hline
\end{tabular}

This table presents the sample selection process for the AAER sample in Panel A and the population in Panel B. We require the population to have the same sample period as the final AAER sample. Panel C compares the mean and median values of firm characteristics between the AAER sample and the propensity-score-matched non-AAER sample. We generate the propensity-score-matched sample by first estimating the logistic model of all-one strings (all-one string f $_{t}$ on size, book-to-market ratio, leverage, and change in return-on-assets $\left(S I Z E_{i t-1}, B T M_{i t-1}, L E V_{i t-1}\right.$, and $\left.\triangle R O A_{i t-1}\right)$ using the AAER sample and the population. We then match each AAER string observation to one string observation in the population, based on the estimated propensity score from the first stage regression. The matching is without replacement and uses a caliper level of three percent. The final AAER sample includes 392 AAER firmyear observations for 136 unique AAER firms. The matched sample includes 392 propensity-scorematched non-AAER observations. The final population includes 43,939 non-AAER firm-year observations. The sample period is from 1985 to 2010 . 
TABLE 2

Triggers for SEC Investigation

\begin{tabular}{|c|c|c|c|c|}
\hline \multirow[t]{2}{*}{ Triggers for SEC investigation } & \multicolumn{2}{|c|}{$\begin{array}{l}\text { All AAERs } \\
(\mathrm{N}=136)\end{array}$} & \multicolumn{2}{|c|}{$\begin{array}{c}\text { All-one string } \\
\text { AAER firms } \\
(\mathrm{N}=85)\end{array}$} \\
\hline & $\mathrm{N}$ & $\%$ & $\mathrm{~N}$ & $\%$ \\
\hline Financial restatements & 79 & $58 \%$ & 46 & $54 \%$ \\
\hline $\begin{array}{l}\text { SEC initiated investigations triggered by } \\
\text { third-party transactions and asset write-offs, etc. }\end{array}$ & 22 & $16 \%$ & 17 & $20 \%$ \\
\hline Shareholder class action / M\&A lawsuits & 18 & $13 \%$ & 10 & $12 \%$ \\
\hline Other government agencies (e.g., FBI and Justice department) & 7 & $5 \%$ & 5 & $6 \%$ \\
\hline Press initiated & 4 & $3 \%$ & 3 & $4 \%$ \\
\hline Whistleblower & 2 & $1 \%$ & 2 & $2 \%$ \\
\hline Short seller initiated & 2 & $1 \%$ & 0 & $0 \%$ \\
\hline Analyst initiated & 1 & $1 \%$ & 1 & $1 \%$ \\
\hline Other / unclear & 1 & $1 \%$ & 1 & $1 \%$ \\
\hline SEC initiated after observing positive earnings strings & 0 & $0 \%$ & 0 & $0 \%$ \\
\hline
\end{tabular}

This table presents the reasons triggering the SEC investigation for our full sample of 136 unique AAERs and for the subsample of 85 AAERs with at least one all-one string during the manipulation period. We obtain this information by searching for news and press releases on Factiva and Google. We confirm that there are no cases where a string of consecutive earnings beats was stated by the SEC as a motivation for investigation. 
TABLE 3

Comparison of Permutations of a Four-Quarter String during Manipulation Years across the AAER Sample, the Population, and the Matched Non-AAER Sample

\begin{tabular}{|c|c|c|c|c|c|c|}
\hline \multirow{2}{*}{ String permutations } & \multicolumn{2}{|c|}{ AAER sample } & \multicolumn{2}{|c|}{ Population } & \multicolumn{2}{|c|}{ Matched sample } \\
\hline & $\mathrm{N}$ & Percent & $\mathrm{N}$ & Percent & $\mathrm{N}$ & Percent \\
\hline Miss all $(0,0,0,0)$ & 10 & $2.55 \%$ & 2,391 & $5.44 \%$ & 20 & $5.10 \%$ \\
\hline$(1,0,0,0)$ & 7 & $1.79 \%$ & 1,500 & $3.41 \%$ & 14 & $3.57 \%$ \\
\hline$(0,1,0,0)$ & 12 & $3.06 \%$ & 1,204 & $2.74 \%$ & 11 & $2.81 \%$ \\
\hline$(0,0,1,0)$ & 4 & $1.02 \%$ & 1,012 & $2.30 \%$ & 5 & $1.28 \%$ \\
\hline$(0,0,0,1)$ & 8 & $2.04 \%$ & 1,393 & $3.17 \%$ & 13 & $3.32 \%$ \\
\hline Beat one quarter & 31 & $7.91 \%$ & 5,109 & $11.63 \%$ & 43 & $10.97 \%$ \\
\hline$(1,1,0,0)$ & 14 & $3.57 \%$ & 1,900 & $4.32 \%$ & 12 & $3.06 \%$ \\
\hline$(1,0,1,0)$ & 5 & $1.28 \%$ & 994 & $2.26 \%$ & 11 & $2.81 \%$ \\
\hline$(1,0,0,1)$ & 7 & $1.79 \%$ & 1,241 & $2.82 \%$ & 10 & $2.55 \%$ \\
\hline$(0,1,1,0)$ & 7 & $1.79 \%$ & 1,133 & $2.58 \%$ & 12 & $3.06 \%$ \\
\hline$(0,1,0,1)$ & 5 & $1.28 \%$ & 1,057 & $2.41 \%$ & 8 & $2.04 \%$ \\
\hline$(0,0,1,1)$ & 8 & $2.04 \%$ & 1,353 & $3.08 \%$ & 10 & $2.55 \%$ \\
\hline Beat two quarters & 46 & $11.73 \%$ & 7,678 & $17.47 \%$ & 63 & $16.07 \%$ \\
\hline$(0,1,1,1)$ & 17 & $4.34 \%$ & 2,453 & $5.58 \%$ & 17 & $4.34 \%$ \\
\hline$(1,0,1,1)$ & 18 & $4.59 \%$ & 1,841 & $4.19 \%$ & 18 & $4.59 \%$ \\
\hline$(1,1,0,1)$ & 25 & $6.38 \%$ & 2,329 & $5.30 \%$ & 17 & $4.34 \%$ \\
\hline$(1,1,1,0)$ & 30 & $7.65 \%$ & 3,248 & $7.39 \%$ & 30 & $7.65 \%$ \\
\hline Beat three quarters & 90 & $22.96 \%$ & 9,871 & $22.47 \%$ & 82 & $20.92 \%$ \\
\hline All-one string $(1,1,1,1)$ & 215 & $54.85 \%$ & 18,890 & $42.99 \%$ & 184 & $46.94 \%$ \\
\hline Total & 392 & $100 \%$ & 43,939 & $100 \%$ & 392 & $100 \%$ \\
\hline \multicolumn{2}{|l|}{ Chi-square test } & \multicolumn{2}{|c|}{ All permutations } & \multicolumn{3}{|c|}{ Permutation of $(1,1,1,1)$} \\
\hline \multicolumn{7}{|l|}{ (1) AAER versus population } \\
\hline Chi-square statistic (p-val & & \multicolumn{2}{|c|}{$36.38^{* * *}(0.00)$} & \multicolumn{3}{|c|}{$22.27^{* * *}(0.00)$} \\
\hline \multicolumn{7}{|c|}{ (2) AAER versus propensity-score-matched non-AAER sample } \\
\hline \multicolumn{2}{|c|}{ Chi-square statistic (p-value) } & \multicolumn{2}{|c|}{$16.11(0.37)$} & \multicolumn{3}{|c|}{$4.90^{* *}(0.03)$} \\
\hline
\end{tabular}

This table presents the distribution of four-quarter string permutations across the AAER sample, the population, and the propensity-score-matched non-AAER sample. The AAER sample includes 392 AAER firm-year observations for 136 unique AAER firms. The matched sample includes 392 propensityscore-matched non-AAER firm-year observations. The population includes 43,939 non-AAER firm-year observations. The sample period is from 1985 to 2010. ${ }^{* * *}$ and ${ }^{* *}$ represent statistical significance at the $1 \%$ and 5\% level, respectively, based on two-tailed tests. See Exhibit 2 for string construction. 
TABLE 4

Analysis of the Ability of AAER Firms to Beat Analysts' Forecasts and the Magnitude of the Beat (Earnings Surprise) in the Three Years Prior to and during the Manipulation Period

\begin{tabular}{llcc}
\hline & Average & Median & Median \\
& BEATPCT & SURPRISE_EPS & SURPRISE_\% \\
\hline Panel A: Comparisons for cumulative three-year period & & & \\
AAER firms for the three years before manipulation period & $86.37 \% 1$ & 0.11 & 0.50 \\
Population & $75.15 \%$ & 0.02 & 0.08 \\
Matched Sample & $78.02 \%$ & 0.02 & 0.08 \\
\hline Panel B: AAER firms prior to the manipulation period & & & 0.62 \\
Three years prior to manipulation (Pre3) & $86.26 \%$ & 0.21 & 0.50 \\
Two years prior to manipulation (Pre2) & $86.64 \%$ & 0.11 & 0.38 \\
One year prior to manipulation (Pre1) & $85.14 \%$ & 0.07 & 0.07 \\
\hline Panel C: AAER firms during the manipulation period & & & 0.05 \\
First manipulation year & $79.04 \% 2$ & 0.02 & \\
The entire manipulation period & $74.63 \%$ & 0.01 & -0.02 \\
\hline Panel D: AAER firms after the manipulation period & & & \\
First year after manipulation ends (Post1) & $57.17 \% 3$ & 0.00 & \\
\hline
\end{tabular}

Panel A reports the average percentage of quarters that AAER firms beat analysts' forecasts (BEATPCT) and the median magnitude of earnings surprise in the three years prior to manipulation. The population and propensity-score-matched sample are matched to each AAER firm in the first year of manipulation. We determine the timeline of variable measurement for the population as follows: Assume that an AAER firm's first manipulation year is 2000, we use all non-AAER firms as of year 2000 as the AAER firm's year-matched population. We then move backward from 2000 to determine the prior three years for the population. The timeline of variable measurement for the matched sample is determined in the same way as for the population. SURPRISE_EPS and SURPRISE_\% are calculated on a firm-quarter basis and then for each firm we calculate the average surprise across quarters. Table 4 reports the median of the firm averages. See Appendix B for variable definitions.

${ }^{1}$ Significantly different from both control groups at the $1 \%$ level.

${ }^{2}$ Significantly different from AAER firms for the three years before manipulation period at the $5 \%$ level.

${ }^{3}$ Significantly different from AAER firms in the first manipulation year at the $1 \%$ level. 
TABLE 5

Market Pressure Proxies for AAER Firms and Non-AAER Firms during the Manipulation Period

Panel A: Comparison between the full sample of AAER firm-years and the population.

\begin{tabular}{|c|c|c|c|c|}
\hline \multirow{2}{*}{ Variable } & \multirow{2}{*}{$\begin{array}{c}\text { AAER sample } \\
(\mathrm{N}=392)\end{array}$} & \multirow{2}{*}{$\begin{array}{c}\text { Population } \\
(\mathrm{N}=43,939)\end{array}$} & \multicolumn{2}{|c|}{ t-test: AAER minus population } \\
\hline & & & Mean diff. & t-statistic \\
\hline \multicolumn{5}{|c|}{ Market pressure from analysts } \\
\hline$L T G_{i t-1}$ & $19.59 \%$ & $16.84 \%$ & $2.75 \%{ }^{* * *}$ & 6.06 \\
\hline$B U Y P C T_{i t-1}$ & $67.37 \%$ & $56.64 \%$ & $10.73 \%^{* * *}$ & 7.44 \\
\hline$R E C M D_{i t-1}$ & 4.01 & 3.75 & $0.26^{* * *}$ & 7.35 \\
\hline \multicolumn{5}{|c|}{ Market pressure from investors } \\
\hline$P E_{i t-1}$ & 40.05 & 30.78 & $9.27^{* * *}$ & 2.70 \\
\hline$I_{H E L D_{i t-1}}$ & $59.22 \%$ & $49.36 \%$ & $9.86 \%{ }^{* * *}$ & 7.08 \\
\hline
\end{tabular}

Panel B: Comparison for all-one strings between AAER firm-years and the population.

\begin{tabular}{|c|c|c|c|c|}
\hline \multirow{2}{*}{ Variable } & \multirow{2}{*}{$\begin{array}{l}\text { AAER all-one strings } \\
\qquad(\mathrm{N}=215)\end{array}$} & \multirow{2}{*}{$\begin{array}{l}\text { Population all-one strings } \\
\qquad(\mathrm{N}=18,890)\end{array}$} & \multicolumn{2}{|c|}{ t-test: AAER minus population } \\
\hline & & & Mean diff. & t-statistic \\
\hline \multicolumn{5}{|c|}{ Market pressure from analysts } \\
\hline$L T G_{i t-1}$ & $20.22 \%$ & $16.93 \%$ & $3.29 \%{ }^{* * *}$ & 5.30 \\
\hline$B U Y P C T_{i t-1}$ & $69.66 \%$ & $60.79 \%$ & $8.87 \%{ }^{* * *}$ & 4.66 \\
\hline$R E C M D_{i t-1}$ & 4.05 & 3.83 & $0.22^{* * *}$ & 4.56 \\
\hline \multicolumn{5}{|c|}{ Market pressure from investors } \\
\hline$P E_{i t-1}$ & 54.41 & 44.95 & $9.46^{*}$ & 1.86 \\
\hline IHELD $_{i t-1}$ & $58.43 \%$ & $51.90 \%$ & $6.53 \%{ }^{* * *}$ & 3.57 \\
\hline
\end{tabular}

Panel C: Comparison between the full sample of AAER firm-years and the matched non-AAER firms.

\begin{tabular}{|c|c|c|c|c|}
\hline \multirow{2}{*}{ Variable } & \multirow{2}{*}{$\begin{array}{l}\text { AAER sample } \\
\quad(\mathrm{N}=392)\end{array}$} & \multirow{2}{*}{$\begin{array}{l}\text { Matched non-AAER } \\
\qquad(\mathrm{N}=392)\end{array}$} & \multicolumn{2}{|c|}{ t-test: AAER minus Non-AAER } \\
\hline & & & Mean diff. & t-statistic \\
\hline \multicolumn{5}{|c|}{ Market pressure from analysts } \\
\hline$L T G_{i t-1}$ & $19.59 \%$ & $16.80 \%$ & $2.79 \%{ }^{* * *}$ & 4.10 \\
\hline$B U Y P C T_{i t-1}$ & $67.37 \%$ & $59.78 \%$ & $7.59 \%{ }^{* * *}$ & 3.52 \\
\hline$R E C M D_{i t-1}$ & 4.01 & 3.79 & $0.22^{* * *}$ & 4.52 \\
\hline \multicolumn{5}{|c|}{ Market pressure from investors } \\
\hline$P E_{i t-1}$ & 40.05 & 32.54 & 7.51 & 1.58 \\
\hline$I_{H E L D_{i t-1}}$ & $59.22 \%$ & $50.42 \%$ & $8.80 \%{ }^{* * *}$ & 4.45 \\
\hline
\end{tabular}

This table compares market pressure proxies across AAER firms, the population, and the propensityscore-matched non-AAER firms. Panel A compares the full sample of AAER firms and the population. Panel B compares AAER all-one strings and population all-one strings. Panel C compares the full sample of AAER firms and the propensity-score-matched non-AAER firms. We report the number of observations for each sample based on the variable that has the most observations. All-one string is a requirement that the firm beats the median analyst consensus forecast in all four quarters of the year. ${ }^{* * *}$, and ${ }^{*}$ represent statistical significance at the $1 \%$, and $10 \%$ level, respectively, based on two-tailed tests. See Exhibit 2 for string construction and Appendix B for variable definitions. 
TABLE 6

CEO Pressure Proxies for AAER Firms and Non-AAER Firms during the Manipulation Period

Panel A: Comparison between the full sample of AAER firms and the population.

\begin{tabular}{|c|c|c|c|c|}
\hline \multirow{2}{*}{ Variable } & \multirow{2}{*}{$\begin{array}{c}\text { AAER sample } \\
(\mathrm{N}=212)\end{array}$} & \multirow{2}{*}{$\begin{array}{l}\text { Population } \\
(\mathrm{N}=17,373)\end{array}$} & \multicolumn{2}{|c|}{ t-test: AAER minus population } \\
\hline & & & Mean diff. & t-statistic \\
\hline \multicolumn{5}{|l|}{ CEO overconfidence } \\
\hline OVERCONFIDENT $T_{i t-1}$ & $58.90 \%$ & $47.54 \%$ & $11.36 \%{ }^{* * *}$ & 2.92 \\
\hline \multicolumn{5}{|l|}{ CEO compensation } \\
\hline SENSITIVITY $_{i t-1}$ & $39.10 \%$ & $29.84 \%$ & $9.26 \%{ }^{* * *}$ & 5.34 \\
\hline \multicolumn{5}{|l|}{ CEO power } \\
\hline PAYSLICE $E_{i t-1}$ & $46.51 \%$ & $40.85 \%$ & $5.66 \%{ }^{* * *}$ & 4.75 \\
\hline$I N D B O A R D_{i t-1}$ & $75.75 \%$ & $80.32 \%$ & $-4.57 \% * * *$ & -4.76 \\
\hline CEOCHAIR $_{i t-1}$ & $76.69 \%$ & $60.93 \%$ & $15.76 \%{ }^{* * *}$ & 4.71 \\
\hline
\end{tabular}

Panel B: Comparison for all-one strings between AAER firms and the population.

\begin{tabular}{lcccc}
\hline Variable & $\begin{array}{c}\text { AAER all-one } \\
\text { strings }(\mathrm{N}=124)\end{array}$ & $\begin{array}{c}\text { Population all-one } \\
\text { strings }(\mathrm{N}=8,608)\end{array}$ & \multicolumn{2}{c}{ t-test: AAER minus population } \\
\cline { 5 - 5 } CEO overconfidence & & & Mean diff. & t-statistic \\
\hline $\begin{array}{l}\text { OVERCONFIDENT } \\
\text { CEO compensation }-1\end{array}$ & $63.54 \%$ & $52.91 \%$ & $10.63 \%^{* *}$ & 2.14 \\
SENSITIVITY $_{i t-1}$ & $39.10 \%$ & $29.84 \%$ & & \\
CEO power & & & $9.26 \%^{* * * *}$ & 4.47 \\
PAYSLICE $_{i t-1}$ & $46.51 \%$ & $40.85 \%$ & $5.66 \%^{* * *}$ & 4.41 \\
INDBOARD $_{i t-1}$ & $74.31 \%$ & $79.86 \%$ & $-5.55 \%^{* * *}$ & -3.90 \\
CEOCHAIR $_{i t-1}$ & $73.96 \%$ & $63.23 \%$ & $10.73 \%^{* *}$ & 2.36 \\
\hline
\end{tabular}

Panel C: Comparison between the full sample of AAER firms and the matched non-AAER firms.

\begin{tabular}{lcccc}
\hline Variable & $\begin{array}{c}\text { AAER sample } \\
(\mathrm{N}=188)\end{array}$ & $\begin{array}{c}\text { Matched non-AAER } \\
(\mathrm{N}=188)\end{array}$ & \multicolumn{2}{c}{ t-test: AAER minus Non-AAER } \\
\cline { 4 - 5 } CEO overconfidence & & & Mean diff. & t-statistic \\
\hline $\begin{array}{l}\text { OVERCONFIDENT } \\
\text { it-1 }\end{array}$ & $57.39 \%$ & $54.42 \%$ & $2.97 \%$ & 0.79 \\
CEO compensation $_{\text {SENSITIVITY }}$ & & & & \\
CEO power -1 & $36.78 \%$ & $32.16 \%$ & $4.62 \%^{*}$ & 1.92 \\
PAYSLICE $_{i t-1}$ & & & & \\
INDBOARD $_{i t-1}$ & $45.67 \%$ & $41.25 \%$ & $4.42 \%^{* * *}$ & 3.16 \\
CEOCHAIR $_{i t-1}$ & $78.17 \%$ & $80.77 \%$ & $-2.60 \%^{* * *}$ & -4.02 \\
\hline
\end{tabular}




\section{TABLE 6 (continued)}

This table compares CEO characteristics across AAER firms, the population, and the propensity-scorematched non-AAER firms. Panel A compares the full sample of AAER firms and the population. Panel B compares AAER all-one strings and population all-one strings. Panel $\mathrm{C}$ compares the full sample of AAER firms and the propensity-score-matched non-AAER firms. We report the number of observations for each sample based on the variable that has the most observations. Due to limited coverage of our data sources, ExecuComp and RiskMetrics, CEO related data are only available for 50 percent of both the AAER sample and the population. As a result, our sample size decreases. All-one string is a requirement that the firm beats the median analyst consensus forecast in all four quarters of the year. ${ }^{* * *},{ }^{* *}$, and ${ }^{*}$ represent statistical significance at the $1 \%, 5 \%, 10 \%$ level, respectively, based on two-tailed tests. See Exhibit 2 for string construction and Appendix B for variable definitions. 
TABLE 7

Logistic Regressions Analyzing whether Market Pressure and CEO Characteristics Impact the Likelihood that a Firm Manipulates Earnings

Panel A: Regressions based on AAER firms and the population.

\begin{tabular}{|c|c|c|c|c|c|}
\hline \multirow{2}{*}{ Variables } & \multirow{2}{*}{ Predicted sign } & \multicolumn{4}{|c|}{ Dependent variable $=A A E R_{i t}$} \\
\hline & & (1) & (2) & (3) & (4) \\
\hline INTERCEPT & & $\begin{array}{c}-8.784^{* * * *} \\
(-16.52)\end{array}$ & $\begin{array}{c}-10.666^{* * *} \\
(-10.58)\end{array}$ & $\begin{array}{c}-10.840^{* * *} \\
(-18.97)\end{array}$ & $\begin{array}{c}-14.763^{* * * *} \\
(-17.82)\end{array}$ \\
\hline \multicolumn{6}{|l|}{ Market pressure from analysts } \\
\hline HIGHLTG $_{i t-1}$ & $(+)$ & $\begin{array}{c}0.582^{* * *} \\
(4.04)\end{array}$ & & & $\begin{array}{c}0.502^{* *} \\
(2.27)\end{array}$ \\
\hline$H I G H B U Y P C T_{i t-1}$ & $(+)$ & $\begin{array}{l}-0.181 \\
(-0.90)\end{array}$ & & & $\begin{array}{l}0.421^{*} \\
(1.68)\end{array}$ \\
\hline STRONGBUY ${ }_{i t-1}$ & $(+)$ & $\begin{array}{c}0.564^{* * * *} \\
(3.03)\end{array}$ & & & $\begin{array}{c}1.019^{* * *} \\
(3.60)\end{array}$ \\
\hline \multicolumn{6}{|l|}{ Market pressure from investors } \\
\hline$H I G H P E_{i t-1}$ & $(+)$ & $\begin{array}{c}0.308^{* *} \\
(2.35)\end{array}$ & & & $\begin{array}{l}0.281 \\
(1.36)\end{array}$ \\
\hline RANKIHELD $D_{i t-1}$ & $(+)$ & $\begin{array}{c}0.199^{* * *} \\
(4.29)\end{array}$ & & & $\begin{array}{c}0.330^{* * * *} \\
(3.84)\end{array}$ \\
\hline \multicolumn{6}{|c|}{ CEO overconfidence, compensation, and power } \\
\hline OVERCONFIDENT $T_{i t-1}$ & $(+)$ & & $\begin{array}{c}-0.339^{* *} \\
(-2.38)\end{array}$ & & $\begin{array}{c}-0.543^{* * *} \\
(-2.99)\end{array}$ \\
\hline SENSITIVITY $_{i t-1}$ & $(+)$ & & $\begin{array}{c}0.373^{* * *} \\
(5.17)\end{array}$ & & $\begin{array}{c}0.278^{* * *} \\
(5.49)\end{array}$ \\
\hline PAYSLICE $E_{i t-1}$ & $(+)$ & & $\begin{array}{c}0.318^{* * * *} \\
(5.05)\end{array}$ & & $\begin{array}{c}0.249^{* * * *} \\
(3.97)\end{array}$ \\
\hline$R A N K I N D B O A R D_{i t-1}$ & $(-)$ & & $\begin{array}{c}-0.260^{* * *} \\
(-6.74)\end{array}$ & & $\begin{array}{c}-0.178^{* * * *} \\
(-3.84)\end{array}$ \\
\hline CEOCHAIR $_{i t-1}$ & $(+)$ & & $\begin{array}{c}0.467^{* * *} \\
(2.28)\end{array}$ & & $\begin{array}{c}0.529^{* *} \\
(2.05)\end{array}$ \\
\hline \multicolumn{6}{|l|}{ Reputation for beating expectations } \\
\hline BEATPCT $_{\text {Prior } 3 Y}$ & $(+)$ & & & $\begin{array}{c}2.992^{* * * *} \\
(5.61)\end{array}$ & $\begin{array}{c}\text { 3.133 }^{* * * *} \\
(4.02)\end{array}$ \\
\hline \multicolumn{6}{|c|}{ Accounting flexibility and other firm characteristics } \\
\hline RANKFSCORE $_{i t}$ & $(+)$ & $\begin{array}{c}0.211^{* * *} \\
(8.78)\end{array}$ & $\begin{array}{c}0.143^{* * *} \\
(4.21)\end{array}$ & $\begin{array}{c}0.196^{* * *} \\
(7.49)\end{array}$ & $\begin{array}{c}0.071^{* *} \\
(2.05)\end{array}$ \\
\hline$S I Z E_{i t-1}$ & $(?)$ & $\begin{array}{c}0.265^{\text {**** }} \\
(5.45)\end{array}$ & $\begin{array}{c}0.345^{* * *} \\
(4.72)\end{array}$ & $\begin{array}{c}0.281^{\text {**** }} \\
(5.86)\end{array}$ & $\begin{array}{c}0.418^{* * * *} \\
(9.56)\end{array}$ \\
\hline$L E V_{i t-1}$ & $(?)$ & $\begin{array}{c}-0.858^{* * * *} \\
(-4.21)\end{array}$ & $\begin{array}{l}-0.708^{*} \\
(-1.84)\end{array}$ & $\begin{array}{c}-0.393^{* *} \\
(-2.19)\end{array}$ & $\begin{array}{l}0.552 \\
(0.95)\end{array}$ \\
\hline$\Delta R O A_{i t-1}$ & $(?)$ & $\begin{array}{l}-1.102 \\
(-1.32)\end{array}$ & $\begin{array}{l}1.795 \\
(0.75)\end{array}$ & $\begin{array}{c}-1.915^{* *} \\
(-2.13)\end{array}$ & $\begin{array}{l}-1.078 \\
(-0.79)\end{array}$ \\
\hline Year and industry fixed effects & & Yes & Yes & Yes & Yes \\
\hline Number of AAER firm-years & & 371 & 118 & 219 & 93 \\
\hline Number of non-AAER firm-years & & 39,634 & 9,175 & 32,997 & 8,455 \\
\hline Pseudo $\mathrm{R}^{2}$ & & $9.81 \%$ & $15.67 \%$ & $10.12 \%$ & $19.88 \%$ \\
\hline
\end{tabular}


TABLE 7 (continued)

Panel B: Regressions based on AAER firms and the matched non-AAER firms.

\begin{tabular}{|c|c|c|c|c|c|}
\hline \multirow{2}{*}{ Variables } & \multirow{2}{*}{$\begin{array}{l}\text { Predicted } \\
\text { sign }\end{array}$} & \multicolumn{4}{|c|}{ Dependent variable $=A A E R_{i t}$} \\
\hline & & $(1)$ & $(2)$ & $(3)$ & $(4)$ \\
\hline INTERCEPT & & $\begin{array}{c}-3.005^{* * * *} \\
(-3.67)\end{array}$ & $\begin{array}{c}-5.622^{* * * *} \\
(-4.12)\end{array}$ & $\begin{array}{c}-5.241^{* * * *} \\
(-5.47)\end{array}$ & $\begin{array}{c}-18.951^{* * * *} \\
(-5.50)\end{array}$ \\
\hline \multicolumn{6}{|l|}{ Market pressure from analysts } \\
\hline$H I G H L T G_{i t-1}$ & $(+)$ & $\begin{array}{c}0.535^{* *} \\
(2.02)\end{array}$ & & & $\begin{array}{c}2.161^{* * *} \\
(4.20)\end{array}$ \\
\hline$H I G H B U Y P C T_{i t-1}$ & $(+)$ & $\begin{array}{c}-0.531^{* *} \\
(-2.05)\end{array}$ & & & $\begin{array}{c}1.844^{* * *} \\
(3.68)\end{array}$ \\
\hline$S T R O N G B U Y_{i t-1}$ & $(+)$ & $\begin{array}{c}0.759^{* * * *} \\
(2.93)\end{array}$ & & & $\begin{array}{c}4.324^{* * *} \\
(3.48)\end{array}$ \\
\hline \multicolumn{6}{|l|}{ Market pressure from investors } \\
\hline$H_{H G H P E_{i t-1}}$ & $(+)$ & $\begin{array}{c}0.404^{* * *} \\
(2.05)\end{array}$ & & & $\begin{array}{l}-0.002 \\
(-0.00)\end{array}$ \\
\hline RANKIHELD $D_{i t-1}$ & $(+)$ & $\begin{array}{c}0.258^{* * * *} \\
(3.78)\end{array}$ & & & $\begin{array}{c}0.772^{* * * *} \\
(3.09)\end{array}$ \\
\hline \multicolumn{6}{|c|}{ CEO overconfidence, compensation, and power } \\
\hline OVERCONFIDENT $T_{i t-1}$ & $(+)$ & & $\begin{array}{l}0.329 \\
(0.80)\end{array}$ & & $\begin{array}{l}1.091^{*} \\
(1.86)\end{array}$ \\
\hline SENSITIVITY $_{i t-1}$ & $(+)$ & & $\begin{array}{c}2.536^{* * *} \\
(2.69)\end{array}$ & & $\begin{array}{c}3.890^{* * *} \\
(2.87)\end{array}$ \\
\hline PAYSLICE $E_{i t-1}$ & $(+)$ & & $\begin{array}{c}6.217^{* * * *} \\
(3.22)\end{array}$ & & $\begin{array}{l}4.304 \\
(1.50)\end{array}$ \\
\hline$R_{A N K I N D B O A R D_{i t-1}}$ & $(-)$ & & $\begin{array}{c}-0.353^{* * *} \\
(-3.41)\end{array}$ & & $\begin{array}{l}-0.290^{*} \\
(-1.69)\end{array}$ \\
\hline CEOCHAIR $_{i t-1}$ & $(+)$ & & $\begin{array}{c}1.380^{* * * *} \\
(2.59)\end{array}$ & & $\begin{array}{c}1.635^{* * * *} \\
(2.67)\end{array}$ \\
\hline \multicolumn{6}{|l|}{ Reputation for beating expectations } \\
\hline${ }_{B E A T P C} T_{\text {Prior } 3 Y}$ & $(+)$ & & & $\begin{array}{c}3.327^{* * * *} \\
(\mathbf{5 . 3 4})\end{array}$ & $\begin{array}{c}9.167^{* * * *} \\
(3.74)\end{array}$ \\
\hline \multicolumn{6}{|c|}{ Accounting flexibility and other firm characteristics } \\
\hline $\operatorname{RANKFSCORE}_{i t}$ & $(+)$ & $\begin{array}{c}0.234^{* * * *} \\
(7.38)\end{array}$ & $\begin{array}{c}0.166^{* * *} \\
(2.62)\end{array}$ & $\begin{array}{c}0.207^{* * *} \\
(4.36)\end{array}$ & $\begin{array}{c}0.476^{* * *} \\
(3.26)\end{array}$ \\
\hline$S I Z E_{i t-1}$ & $(?)$ & $\begin{array}{l}-0.061 \\
(-0.88)\end{array}$ & $\begin{array}{l}-0.152 \\
(-1.06)\end{array}$ & $\begin{array}{l}-0.078 \\
(-0.98)\end{array}$ & $\begin{array}{l}0.045 \\
(0.19)\end{array}$ \\
\hline$L E V_{i t-1}$ & $(?)$ & $\begin{array}{c}0.955^{* *} \\
(2.38)\end{array}$ & $\begin{array}{c}1.356^{* *} \\
(2.06)\end{array}$ & $\begin{array}{c}1.515^{* * *} \\
(2.74)\end{array}$ & $\begin{array}{c}2.857^{* *} \\
(2.34)\end{array}$ \\
\hline$\Delta R O A_{i t-1}$ & $(?)$ & $\begin{array}{l}-0.574 \\
(-0.68)\end{array}$ & $\begin{array}{c}5.685^{* * *} \\
(3.05)\end{array}$ & $\begin{array}{l}-0.976 \\
(-1.00)\end{array}$ & $\begin{array}{l}2.704 \\
(0.74)\end{array}$ \\
\hline Year and industry fixed effects & & Yes & Yes & Yes & Yes \\
\hline Number of AAER firm-years & & 371 & 118 & 219 & 93 \\
\hline Number of matched non-AAER firm-yea & ears & 371 & 118 & 219 & 93 \\
\hline Pseudo $\mathrm{R}^{2}$ & & $17.71 \%$ & $29.68 \%$ & $18.55 \%$ & $44.84 \%$ \\
\hline
\end{tabular}




\section{TABLE 7 (continued)}

This table reports the results from logistic regressions of financial misstatement (AAER $i t$ equals 1 for a manipulation year, and zero otherwise) on motivating factors (e.g., market pressure and CEO characteristics), along with a wide array of control variables. Panel A is based on AAER firms and the population, and Panel B is based on AAER firms and the propensity-score-matched non-AAER firms. Industry fixed effects are based on Fama and French's (1997) 12-industry classification. Standard errors are clustered by year. ${ }^{* * *},{ }^{* *}$, and * represent statistical significance at the 1\%, 5\%, $10 \%$ level, respectively, based on two-tailed tests. The z-statistics are reported in parentheses. See Appendix B for variable definitions. Bold text indicates variables of interest. 